MARITIME SEDIMENTS AND ATLANTIC GEOLOGY

\title{
Alluvial fan and piedmont sedimentation in the Tynemouth Creek Formation (Lower Pennsylvanian) of southern New Brunswick
}

\author{
A.G. Plint and H.W. van de Poll, Department of Geology \\ University of New Brunswick, P.O. Box 4400, Fredericton, N.B., Canada E3B 5A3
}

\begin{abstract}
The Tynemouth Creek Formation (formerly the Tynemouth Creek and McCoy Head Formation) is redefined and detailed stratigraphic and structural sections through representative parts of the formation are presented. The Tynemouth Creek Formation is of Lower Pennsylvanian age and is at least $800 \mathrm{~m}$ thick. It is dominantly clastic, shows an overall upward-coarsening from siltstones and sandstones into conglomerates and was deposited in an alluvial fan and piedmont setting. Six sedimentary facies are recognized. (1) Coarse, polymlct, clast-supported conglomerates dominate the upper part of the formation. (2) Tabular and channelized pebbly sandstones, up to $8 \mathrm{~m}$ thick represent braided channels, the former characterfzed by unstable banks and laterally migrating channels while the latter may have formed on the upper fan when periodic tectonic movement caused rejuvenation of the streams and resultant channel incision. (3) Erosive-based sandstones up to $30 \mathrm{~m}$ thick occur near the base of the formation and are interpreted as point-har deposits of large meandering rivers that existed on the floor of the basin beyond the alluvial fan toe. (4) Thin-bedded sandstones and siltstones were deposited on the banks and in abandoned channels of rivers which locally supported dense growths of Calamites. (5) Red siltstones and sheet sandstones were laid down in interchannel and distal fan areas, the former by low-energy flooding and perhaps wind action; the latter by sheet floods. Paleosols and calcitic nodules are characteristic of this facies. (6) In areas starved of clastic sediment, shallow lakes occasionally formed and accumulated thin bioclastic (ostracode/gastropod/spirorbid) or algal limestones. Palaeocurrents are unimodal with a mean flow towards the north-west. The Tynemouth Creek Formation probably represents a sector of a large alluvial fan that built northward from the southern, fault-bounded margin of the Cumberland Basin. The upward-coarsening of the sequence may record continued tectonic rejuvenation of the source area, causing fan progradation and deposition of coarse, fan-head conglomerates over finer, lower fan sediments. A climate of alternating wet and (?hot) dry seasons is inferred from the sedimentary evidence as a whole.
\end{abstract}

La formation de Tynemouth Creek (autrefois les formations de Tynemouth Creek et de McCoy Head) est redéfinie et des coupes stratigraphiques et structurales détaillées, réprésentatives de la formation, sont présentées. La formation de Tynemouth Creek remonte au Pennsylvanien inférieur et mesure au moins $800 \mathrm{~m}$ d'épaisseur. Les roches détritiques y dominent et on perçoit une granulométrie croissante passant des roches limoneuses et des grès aux conglomérats, le tout déposé en milieu de plémont et de cône de déjection.

On reconnaft six faciès sédimentaires. (1) Des conglomérats polymictiques grossiers, se soutenant, caractérisent le sommet de la formation. (2) Des grès calllouteux tabulaires et cannelés mesurant jusqu'à 8 m d'épaisseur représentent des chenaux anastomosés. Les grès tabulaires sont marqués par des berges instables et une migration latêrale des chenaux, tandis que les grès cannelés ont probablement été mis en place sur la portion supérieure du cône, à la suite d'épisodes tectoniques quf provoquèrent le rajeunissement et l'encaissement des cours d'eux. (3) Dans la partie inférieure de la formation, on trouve des grès à base érosive atteignant jusqu'à 30 m d'épaisseur. Ceux-ci sont interprétés conne les bancs de sable en pointe de grandes rivières à méandres qui coulaient dans le bassin, au delà de l'extrémité inférieure du cône de déjection. (4) Les grès et roches 1 imoneuses finement lités furent déposés le long des dives et dans les chenaux abandonnês des rivières où poussait une végétation luxuriante de Calamites. (5) Des roches limoneuses rouges et des grès en nappes furent déposés entre les chenaux ainsi qu'à la périphérie du cône de dêjection: les premières par des crues de faible énergie et peut être par l'action du vent; les seconds par des crues en nappes. Des nodules calcitiques et des paléosols caractérisent ce faciès. (6) Dans les régions dépourvues de sẻdiments dêtritiques, des lacs peu profonds se formèrent à l'occasion et de minces calcaires bioclastiques (ostracodes/gastropodes) ou à alques s'y accumulèrent.

Un groupement unfmodal des paléocourants est noté, avec un vecteur moyen vers le nord-ouest. La formation de Tynemouth Creek correspond probablement à la portion d'un grand cône de déjection qui s'est édiflé en direction nord, à partir de la bordure faillêe du Bassin de Cumberland. La granulométrie croissante de la séquence correspond peut être à un rajeunissement tectonique continuel de la région source, accompagné de la progression du cône ainsi que de la déposition de conglomérats grossiers du cône supérieur sur les sédiments plus fins de la partie inférieure du cône. Un climat marqué par l'alternance entre saison humíde et saison sèche (chaude?) est déduit à partır des données sédimentologiques. 


\section{INTRODUCTION}

The Tynemouth Creek Formation belongs to the Pennsylvanian Cumberland Group, and is probably of Westphalian A or B age (Barss, pers, com.). It outcrops in a relatively small, elongate area on the south coast of New Brunswick, $20 \mathrm{~km}$ east of Saint John. This area is $21 \mathrm{~km}$ long and $8 \mathrm{~km}$ wide and lies immediately to the south of the Caledonia Highlands (Fig. 1). The present paper describes the results of a detailed sedimentological study of the Carboniferous strata exposed between Rogers Head and Emerson Creek (Fig. 2). Similar sediments are exposed from $1.8 \mathrm{~km}$ east of Rogers Head to $600 \mathrm{~m}$ north of Quaco Head (Fig. 1). These rocks are currently under investigation and will be described in a subsequent paper.

The geology of the area was originally mapped in detail by Bailey (1865) with subsequent work by E1ls (1907), Bailey and Matthew (1918), Bell (1927), Hayes and Howell (1937), and Alcock (1938). Kelly (1967) reviewed, in general terms, the stratigraphy of the Maritime Provinces while Belt (1968) described the principal lithofacies and depositional environments of the Carboniferous rocks of the same area. The stratigraphy and sedimentology of the Pennsylvanian of southern New Brunswick was studied by Poll (1970, 1972). Ruitenberg et al. (1979) in a study of the geology and mineral deposits of the Caledonia area briefly examined the coastal exposures of the Tynemouth Creek Formation and followed the stratigraphic nomenclature of Poll (1970).

\section{STRATIGRAPHY}

Sediments of the Tynemouth Creek Formation, are generally in faulted contact with both older and younger rocks. At the western margin of the area, at Emerson Creek, (Fig. 2) it is in faulted contact with the West Beach and Balls Lake Formations of Mississippian or Pennsylvanian age (Alcock, 1938). Twenty $\mathrm{km}$ to the east, at Rogers Head (Fig. 2) beds low in the Tynemouth Creek Forma-

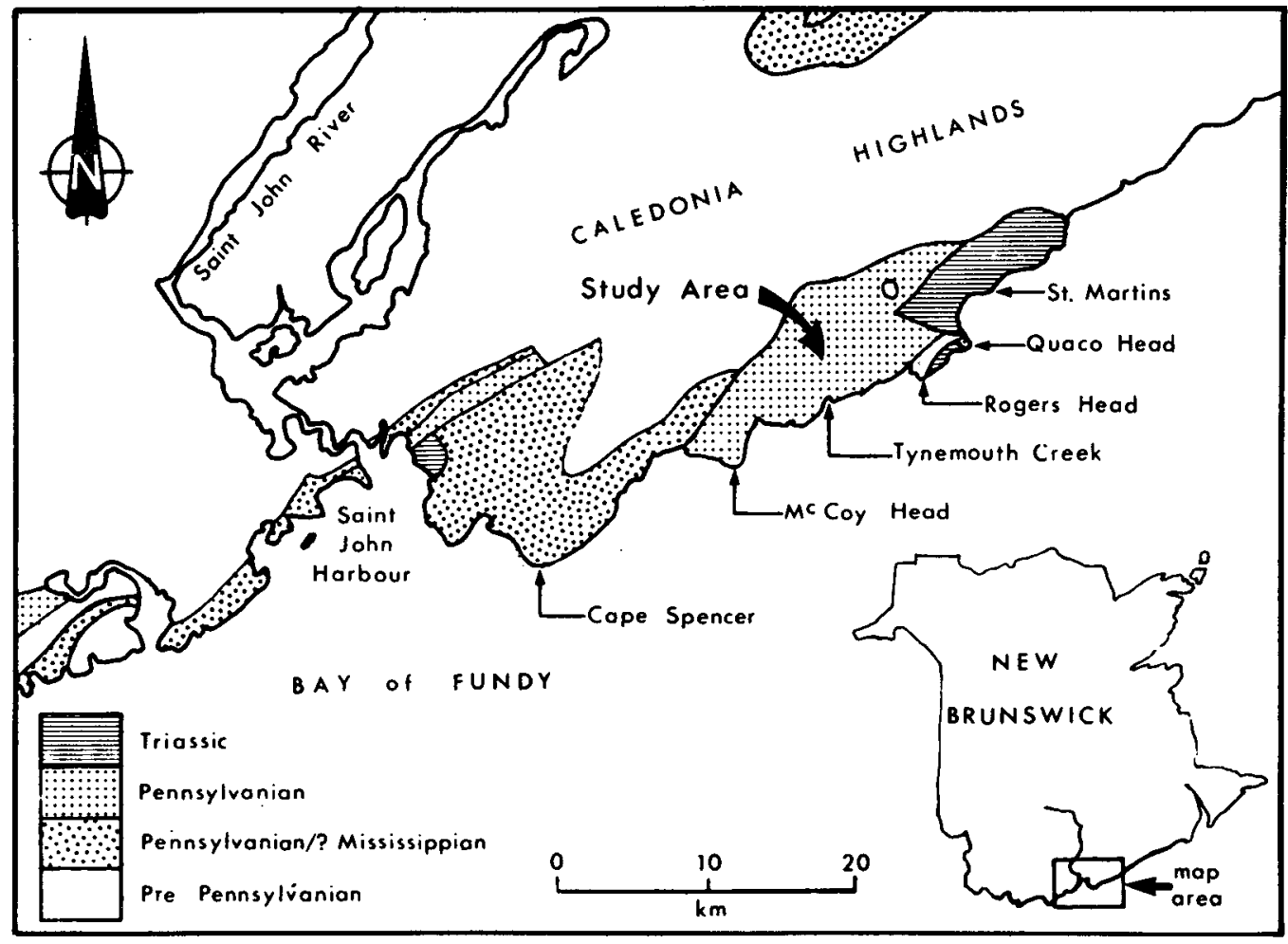

Fig. 1 - Map of the Saint John area, New Brunswlck, showing the distribution of Pennsylvanian rocks and the location of the study area. 


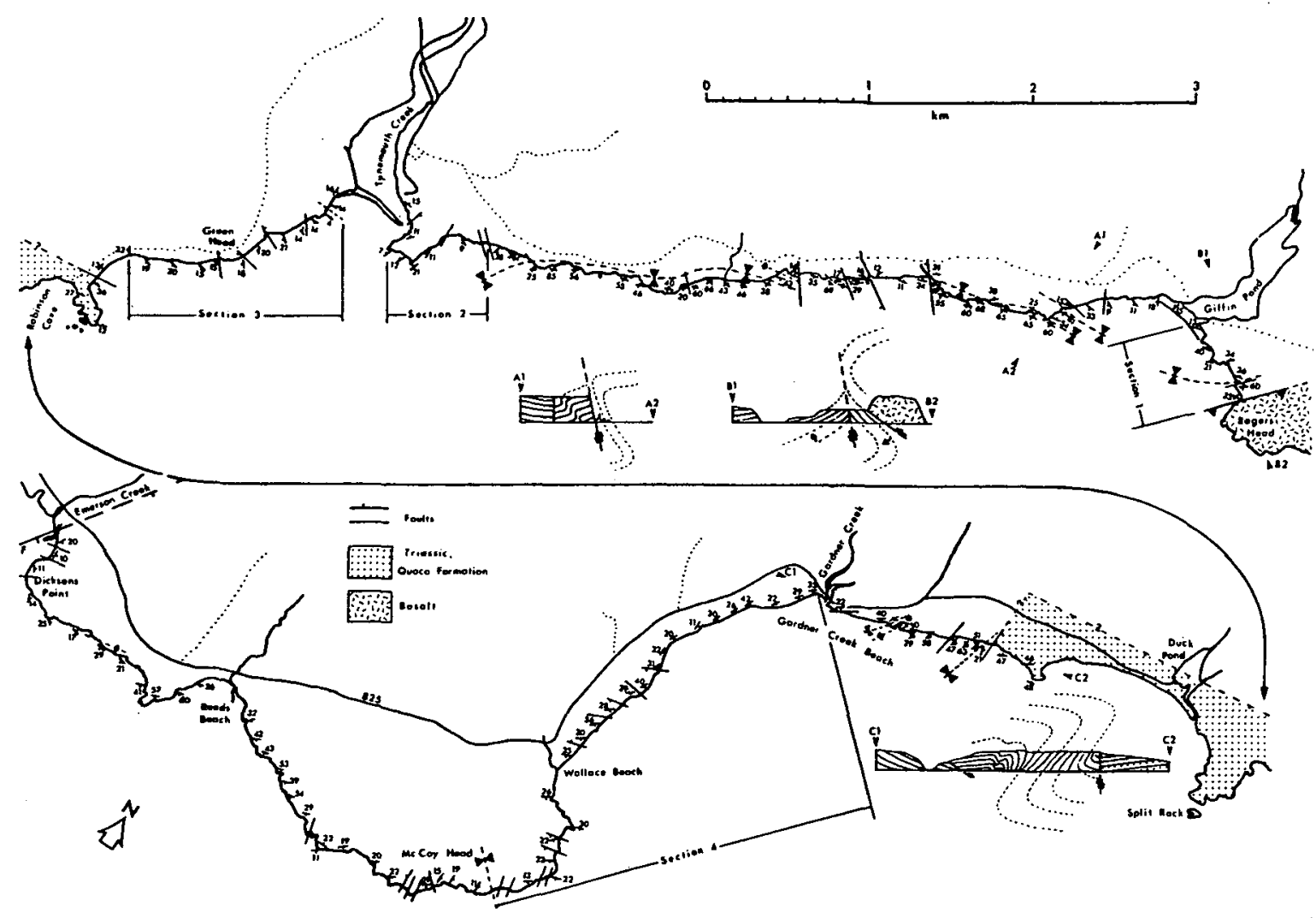

Fig. 2 - Detailed map showing coastal exposures and structure of the Tynemouth Creek Formation. The position of the four measured stratigraphic sections, and three sketch cross-sections are shown. As yet, no means of accurately correlating sections 1-4 has been found.

tion are overturned and faulted against rubbly and amygdaloidal basalts of unknown (?Precambrian, ?Devonian) age.

The Tynemouth Creek Formation comprises siltstones, sandstones and conglomerates and shows an overall upwardcoarsening. The highest beds are exposed on McCoy Head and comprise coarse, thick-bedded conglomerates. The lower part of the Formation is dominantly red or reddish-brown. Towards the top however, yellow and grey sediments become more common.

Bailey (1865) ascribed the Tynemouth Creek Formation to the Lower Carboniferous while E1ls (1907) considered it to belong to the Perry Formation, of Upper Devonian age, Subsequently, Bailey and Matthew (1918) ascribed the Tynemouth Creek Formation to the upper part of the Perry Formation which was thought to be of Lower Carboniferous age. Recent palynological work (Barss, pers, com.) indicates a Lower Pennsylvanian (?Westphalian B) age.

The Tynemouth Creek Formation was divided into a lower, 'McCoy Head For mation', composed mainly of conglomerates, and an upper, 'Tynemouth Creek Formation' dominated by sandstones and siltstones (Hayes and Howell 1937, Alcock 1938). Po11 (1970) recognized the essential lithologic continuity of these two formations and informally grouped them as the McCoy Head Formation (Poll 1972). Detailed examination of the sediments confirms that (i) the two 'Formations' of Hayes and Howell (1937) are clearly intergradational and (ii) that the sandstones and siltstones of the 'Tynemouth Creek Formation' in fact underlie the conglomerates of the 'McCoy Head Formation'. The cliffs in the immediate vicinity of Tynemouth Creek exposed excellent examples of all the prin 

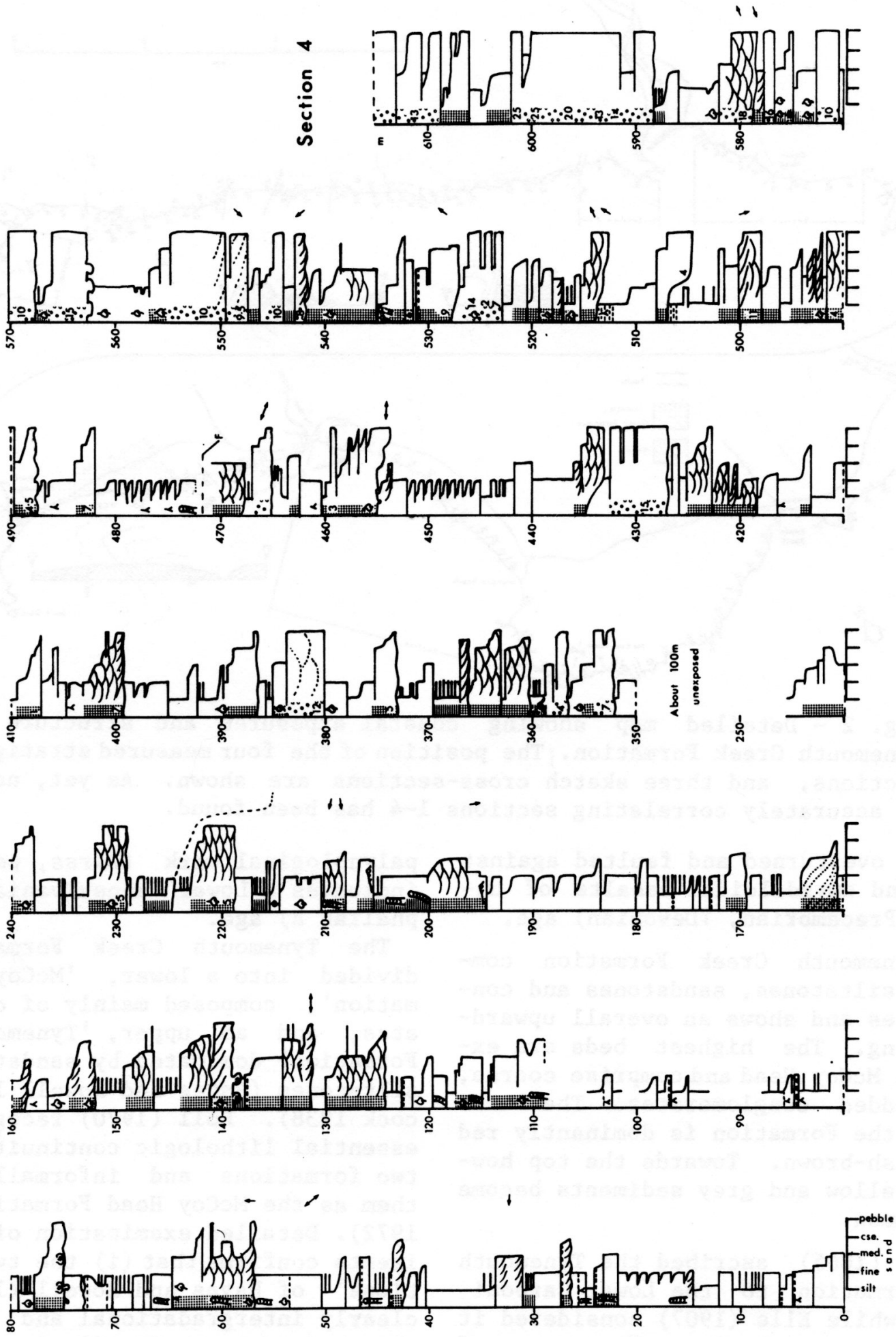

Fig. 3 - Stratigraphic section no. 4. Note overall upwardcoarsening of the sequence with interchannel sediments and palaeosols dominant in the lower part, replaced by braidedriver sandstones and streamflood conglomerates towards the top. 


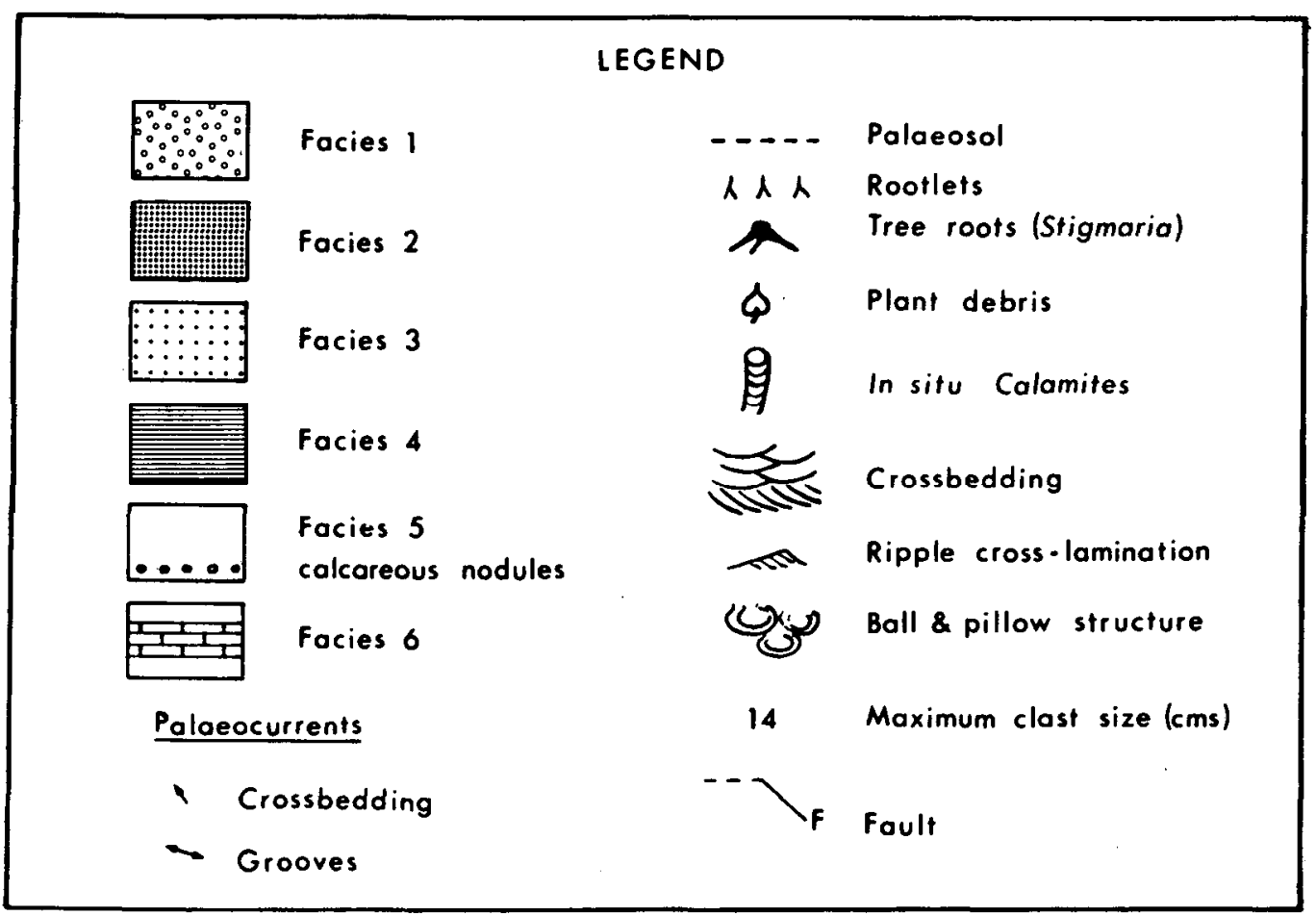

cipal rock types that characterize the formation. This is not the case at McCoy Head, where the succession is dominated by coarse sandstones and conglomerates. It is therefore proposed that the term 'Tynemouth Creek Formation' be adopted to denote all the strata of Lower Pennsylvanian age exposed between Emerson Creek and Rogers Head. The progressive upward coarsening of the formation, clearly seen in Section 4 of this work, (Fig. 3) illustrates the intergradational nature of the two facies and shows that there is no logical basis for their separation.

\section{STRUCTURE}

\section{Folding}

The coastal exposures of the Tynemouth Creek Formation were mapped at $1: 10,000$ using a base-map constructed from aerial photographs. A simplified version of this map is given in Fig. 2 . The Tynemouth Creek Formation to the east of Tynemouth Creek is deformed by one or more large, northward-facing, asymmetrical folds, the axes of which trend ENE-WSW. Beds on the northern limb of each fold are usually overturned and dip to the south from $90^{\circ}$ to $25^{\circ}$.
(Fig. 4). Sedimentary evidence permits easy determination of way-up. Several smaller folds, with amplitudes of a few metres are associated with these major structures.

Between Giffin Pond and Rogers Head, the beds either dip NW at about $30^{\circ}$, or are overturned and dip SE at $50^{\circ}$. (Fig. 2) (cf. early structural section by Bailey 1865, section $\mathrm{H}$ ). The hinge of the fold has sheared out and is seen as a high-angle reverse fault. Displacement on this fault seems to be only a few tens of metres, as similar sedimentary successions can be measured on either side. The lowest beds in this section are overturned and faulted against the basalts that form Rogers Head. The contact is a zone of sheared basalt and red siltstone, up to $50 \mathrm{~cm}$ thick. Thin beds of tuff are intercalated with the basalt and dip at about the same angle as the Tynemouth Creek Formation sediments, suggesting that both the latter and the basalts are part of the same large fold (Fig. 2). It is possible that there has been little differential movement between the two rock units; the sheared contact simply reflects the differential competence of 
the two rock types during deformation.

Between Duck Pond and Gardner Creek Beach, sediments of the Tynemouth Creek Formation are deformed by a large, eastfacing fold, the overturned limb of which is about $300 \mathrm{~m}$ thick (Fig. 2). Several smaller folds are associated with this structure. The synclinal axis of the major fold is seen a few metres west of a fault (unexposed) which separates the Carboniferous from downfaulted Triassic sediments of the Quaco Formation (Powers, 1916). The joint pattern in the rocks of this area has been the subject of recent study (Lajtai and Stringer 1981).

Between Wallace Beach and Reeds Beach, the Tynemouth Creek Formation is deformed into a shallow syncline, the axis of which plunges gently to the south-east. Between Reeds Beach and Emerson Creek faulting and deformation becomes progressively more intense and reaches a maximum adjacent to a major fault that separates the Tynemouth Creek Formation from the West Beach Formation (?Mississippian or Pennsylvanian).

\section{Faulting}

The Tynemouth Creek Formation is cut by numerous faults, most of which have a NW-SE orientation. Most faults are normal and the fault plane usually dips at a high angle. The throw on most faults is usually only a few metres and the sedimentary succession can be correlated across the fault within the dimensions of the exposure.

Occasional reverse faults are associated with major folds, for example, at Gardner Creek Beach and Rogers Head. A major fault, forming the SW boundary of the Tynemouth Creek Formation runs NNE along the east side of Emerson Creek and forms a prominent scarp for over 6 $\mathrm{km}$.

In the area around Split Rock and Robinson Cove, a block of Triassic sandstone of the Quaco Formation (Powers 1916) Is downfaulted against the Carboniferous. The fault, which dips at about $20^{\circ}, 170^{\circ} \mathrm{N}$, is well exposed in the cliff to the east of Robinson Cove.
Sandstone Dikes

Essentially uncompacted sandstone dikes are present in the Tynemouth Creek Formation and, almost invariably, are found in the immediate vicinity of, and approximately parallel to small normal faults. Sandstone dikes show a pronounced preferred orientation throughout the formation (Fig. 5) and probably reflect a regional stress pattern (cf. Harms 1965, Marschalko 1965, Peterson 1966, Eisbacher 1970, Powell 1973). Their association with normal faults suggests that the dikes, which are displaced by the faults, were intruded during a relatively early phase of tensional deformation, and may be considered as precursors of the normal faults that subsequently developed in the same areas.

\section{SEDIMENTS}

The sediments of the Tynemouth Creek Formation are divided into six facies, principally on the basis of bed thickness and geometry, sedimentary structures, grain size and composition. Note: To simplify description, each facies is described under an 'interpretive name', although objective description and interpretation are, as far as possible, kept separate. The sediments have suffered pervasive yet generally unspectacular modification through a variety

$$
\text { Sand dikes }
$$
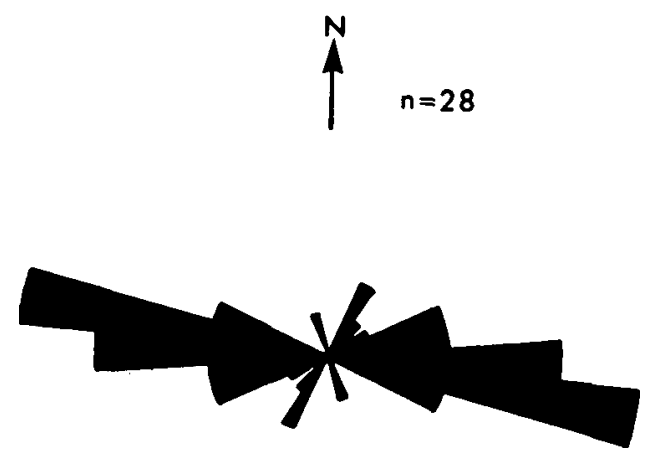

Fig. 5 - Rose diagram showing the orientation of late-stage (post-compaction) sand dikes. Dikes show a marked preferred orlentation reflecting a regional tensional stress regime. 


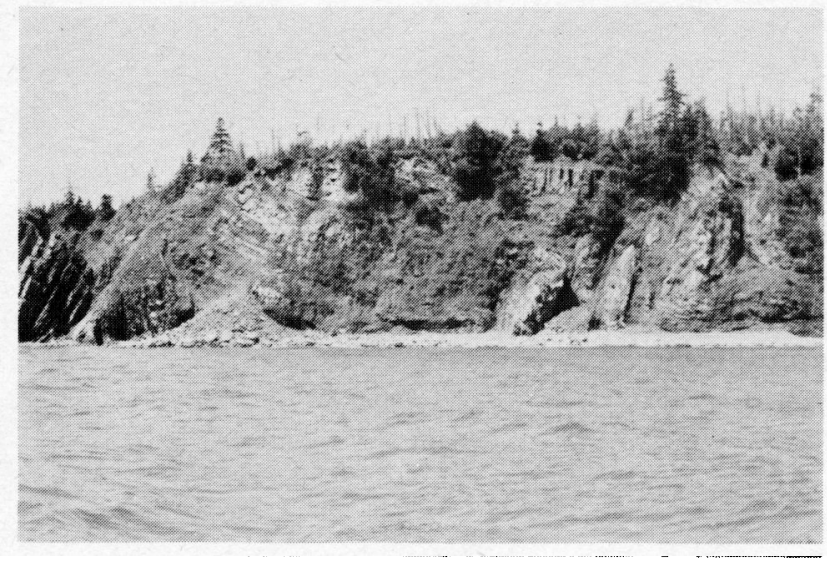

\section{RIGHT}

Fig. 6 - Two, sharp and planar-based streamflood conglomerates of Facies 1 (base of conglomerates arrowed). Note upward gradation of conglomerates into sandstones.

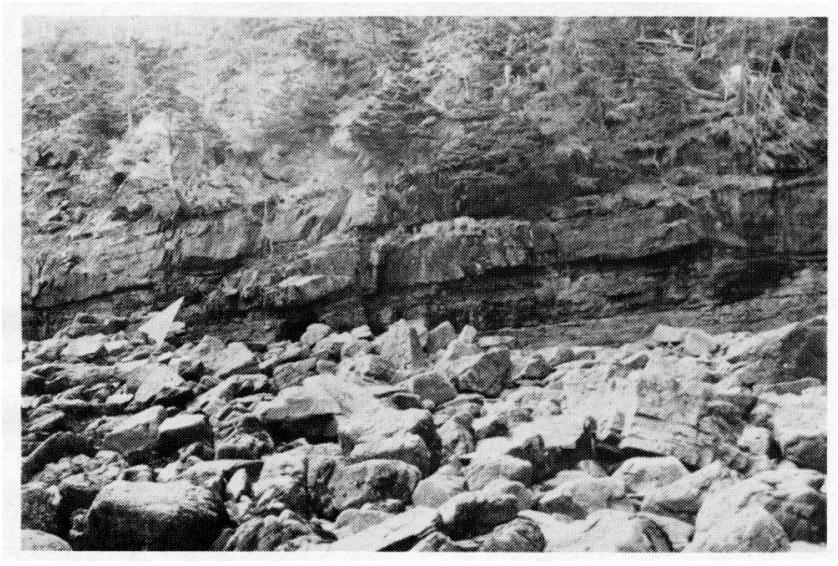

RIGHT

Fig. 8 - Streamflood conglomerates of Facies 1 showing large-scale tabular cross-stratification.
LEFT

Fig. 4 - View of cliffs (facing west) to the SW of Giffin Pond showing northward-facing folds. Beds at the extreme left are overturned.

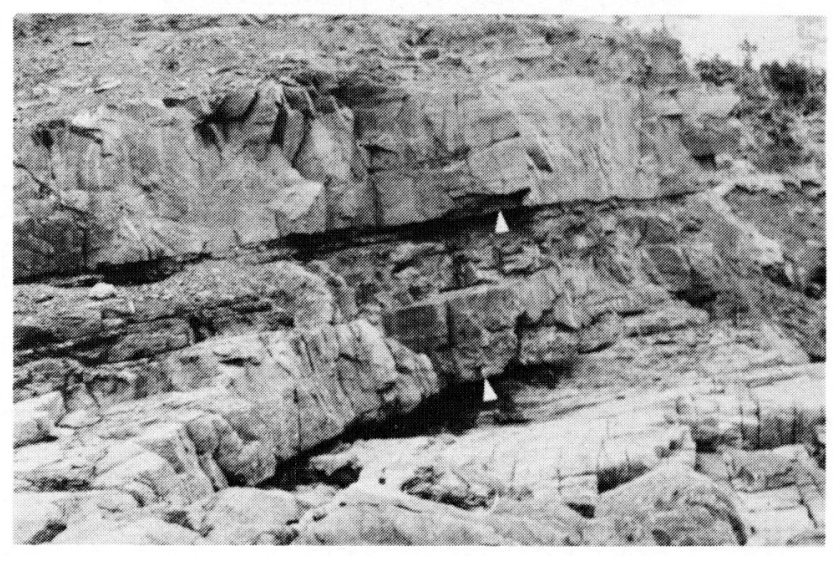

LEFT

Fig. 7-Streamflood conglomerates showing erosion (arrowed) at base of unit.

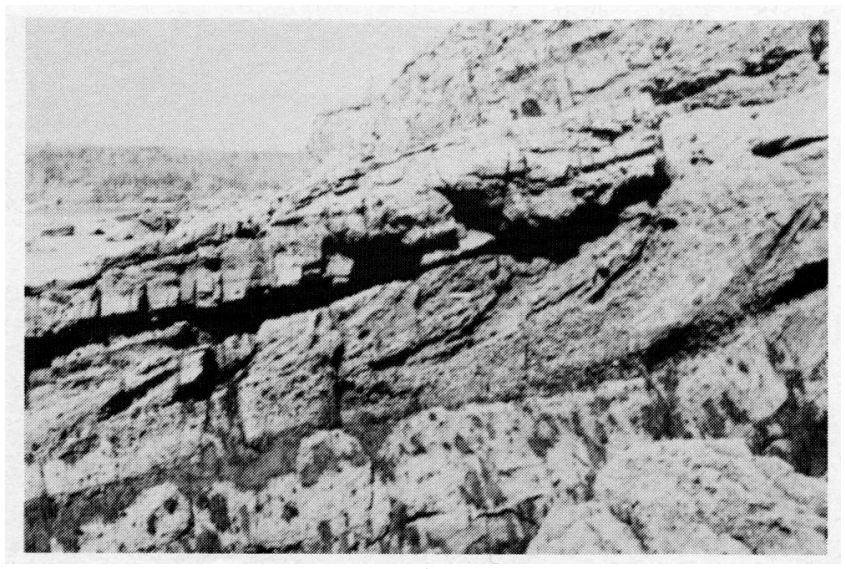




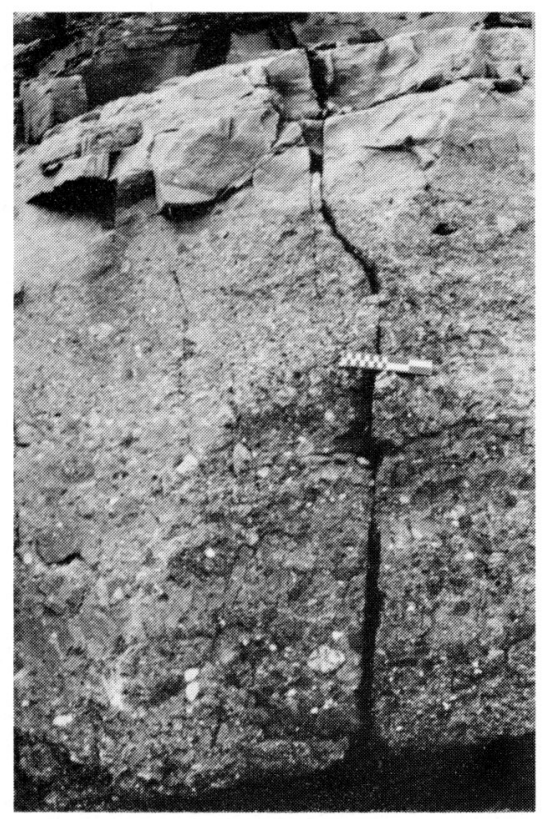

RIGHT

Fig. 10 - Lens of sandstone enclosed by conglomerates of Facies 1. Sandstone preserves small ripples which apparently developed at low stage in a shallow, water-filled depression.

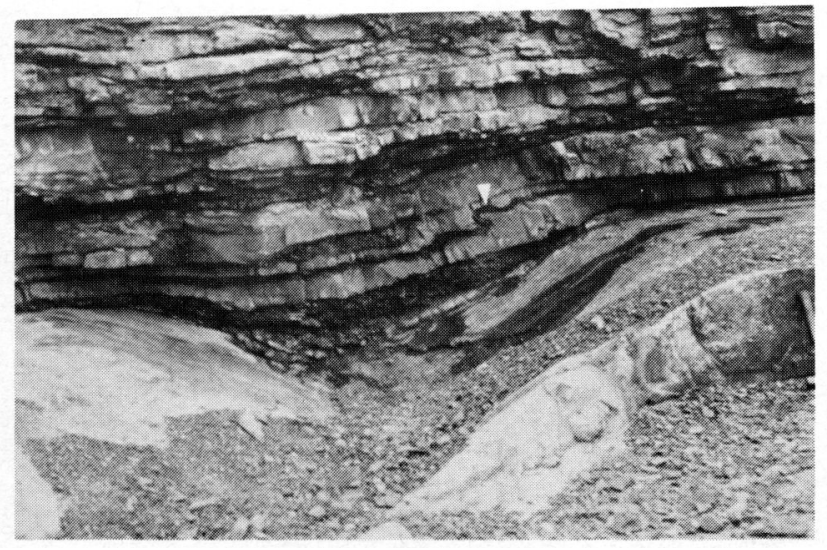

LEFT

Fig. 9 - Sharp-based, clast-supported streamflood conglomerate showing normal grading and upward passage to coarse sandstone.

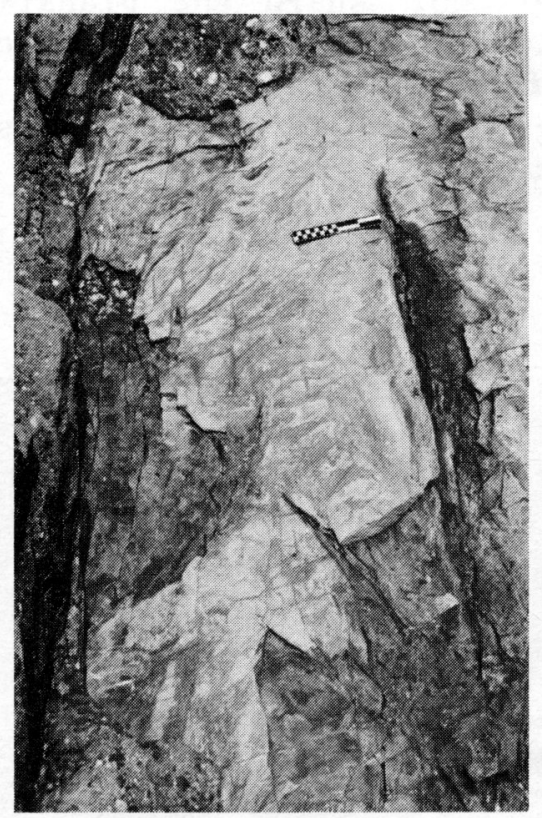

\section{LEFT}

Fig. 11 - Trough-like structures preserved in medium sandstone, immediately above a streamflood conglomerate. The trough is filled with interbedded sandstone and siltstone containing in situ Calamites and small, soft-sediment slump folds (arrowed) on the flank of the depression. 
of physical diagenetic processes, related to post-depositional compaction, dewatering and liquefaction (Plint and Poll 1982). Details of these changes are beyond the scope of this paper and will be presented elsewhere.

\section{Facies 1 - Streamflood Deposits}

Streamflood deposits comprise metrebedded, clast-supported, polymictic conglomerates. Typically, conglomerates have a sharp base which may be planar (Fig. 6) or channeled (Fig. 7). Clasts range up to $250 \mathrm{~mm}$ in diameter. Mean roundness is around $0.5-0.6$ and sorting relatively poor. Conglomerates form units laterally-traceable for tens to hundreds of metres, and from 1.5 to 10 m thick. Conglomerates sometimes display large-scale tabular cross-stratification (Fig. 9) and often show normalgrading, passing upwards into sandstone or pebbly sandstones (Fig. 9). Lenses of sandstone may be present within the conglomerates and occasionally preserve small ripples (Fig. 10, cf. Rust, 1972, fig. 4). At the top of a few conglomerate units, large dune-like forms are present. The sediment filling the troughs may show small, soft-sediment (slump) folds (Fig. 11). Conglomerates comprise a wide variety of clasts which include quartz, quartzite, granite, granophyre, rhyolite, basalt, mylonite and various meta-sediments, together with intraformational siltstone and limestone pebbles and un-metamorphosed arkosic sandstones and limestones, the latter yielding, in some instances, a fauna of Windsor (Lr. Carboniferous) age (Bell 1927). A detailed consideration of this pebble suite is, however, beyond the scope of the present paper:

\section{Interpretation}

The conglomerates of facies 1 are very similar to streamflood deposits described from recent alluvial fans (Blissenbach 1954, Bull 1964) and from ancient alluvial fan deposits (Bluck 1967, McGowen and Groat 1971, Steel 1974, Steel and Wilson 1976, Heward 1978, Gloppen and Steel 1981). Stream- flood deposits represent deposition from a medium less viscous than a mudflow, with a relatively high water: sediment ratio. The pebbles and cobbles represent a traction load, while the sand usually present in the upper part of each conglomerate unit was carried in suspension and deposited during the waning phase of the flood (Bluck 1965, Heward 1978). Streamflood deposits are laid down both in and beyond the margins of large channels on the upper parts of alluvial fans (Bluck 1967, Steel and Wilson 1975).

\section{Facies 2 - Braided River Deposits}

These sediments comprise mainly coarse and medium sand which may be granular or pebbly. Pebbles, which seldom exceed a few centimetres in diameter, are typically well-segregated, forming distinct layers, interbedded with pebble-free sand (Fig. 12). Decimetre-scale trough cross-bedding is the most common primary sedimentary structure and is often associated with horizontal lamination. Sandstone beds may be either tabular or lenticular, and range up to $8 \mathrm{~m}$ thick. Tabular sandstones have a sharp, planar base, often with a pebble lag, and may be traced laterally for many tens or even hundreds of metres with little variation in thickness (Fig. 13). Local$1 y$, however, tabular sandstones thicken to form lenticular channelized masses, tens of metres wide (Fig. 14). The walls of channels range from gently inclined (Fig. 15) to near vertical (Fig. 16) and may be stepped, reflecting differential erosion of the underlying beds (Fig. 17). Sandstones may. show an upward-fining, upward-coarsening or no obvious pattern. Channelized sandstones are usually trough crossbedded and contain pebble-rich pockets which usually are richer in quartzose pebbles than streamflood conglomerates.

\section{Interpretation}

These sediments are very closely comparable to braided stream deposits, such as those described by Steel (1974) and Wilson (1980). Relative to streamflood 
conglomerates, they are finer grained, better sorted and tend to have a more complex internal structure. Abundant cross-bedding indicates turbulent flow while horizontal lamination may have formed under upper flow-regime conditions. Abrupt lateral changes in grain size with pebble-filled pockets suggest local scouring and winnowing of fines.

On rare occasions (eg. Section 3, 76 $\mathrm{m})$, channelized sandstones contain only intraformational limestone pebbles derived through reworking of caliche nodules (Facies 5). The absence of exotic clasts in these unusual sandstones suggests that some channels were headed on the fan surface and not supplied directly from the fan head (cf. Denny 1965, Allen and Williams 1979).
Laterally-extensive, tabular sandstones may be interpreted as the deposits of relatively shallow, perhaps ephemeral channels flowing on the lower part of the fan surface. Intermittent flow and unstable sandy banks permitted rapid lateral migration of the channels and the deposition of relatively thin yet laterally-extensive sandstone bodies (cf. Bluck 1967, conglomerate 'c'; Steel 1974, facies D1).

Channelized sandstones tend to occur in association with conglomerates in the upper part of the formation (upper Section 4, Fig. 3), whereas tabular sand stones are more common in the lower part of the formation, dominated by interchannel and interlobe deposits ( $\mathrm{Lr}$. Section 3, Fig. 18). In view of this,
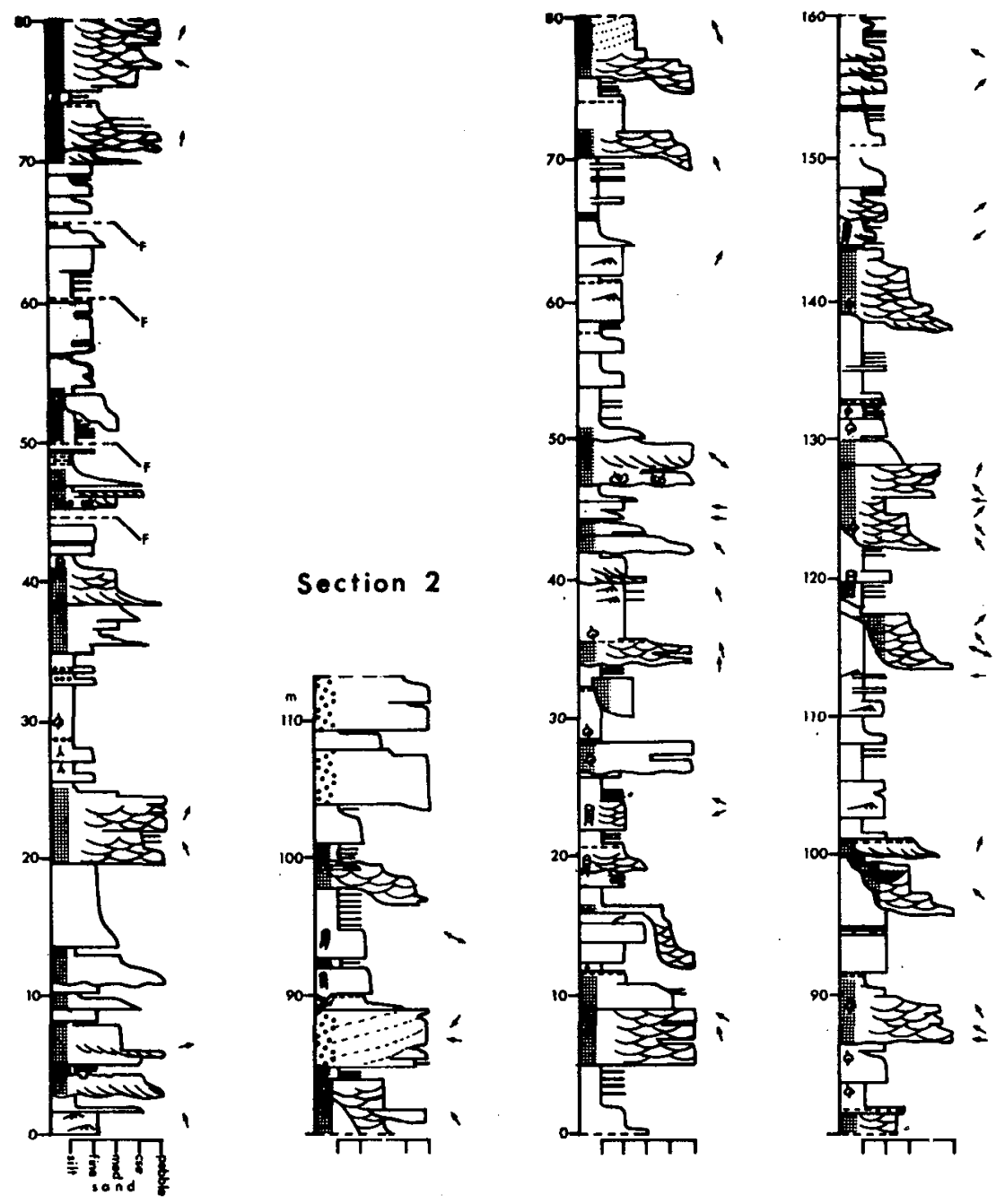

Section 3

Fig. 18 - Stratigraphic sections 2 and 3 , measured to the east and west of Tynemouth Creek. 


\section{RIGHT}

Fig. 12 - Bedded pebbly sandstones of Facies 2 (braided river). Note plane lamination, cross-bedding and pebbly lenses.

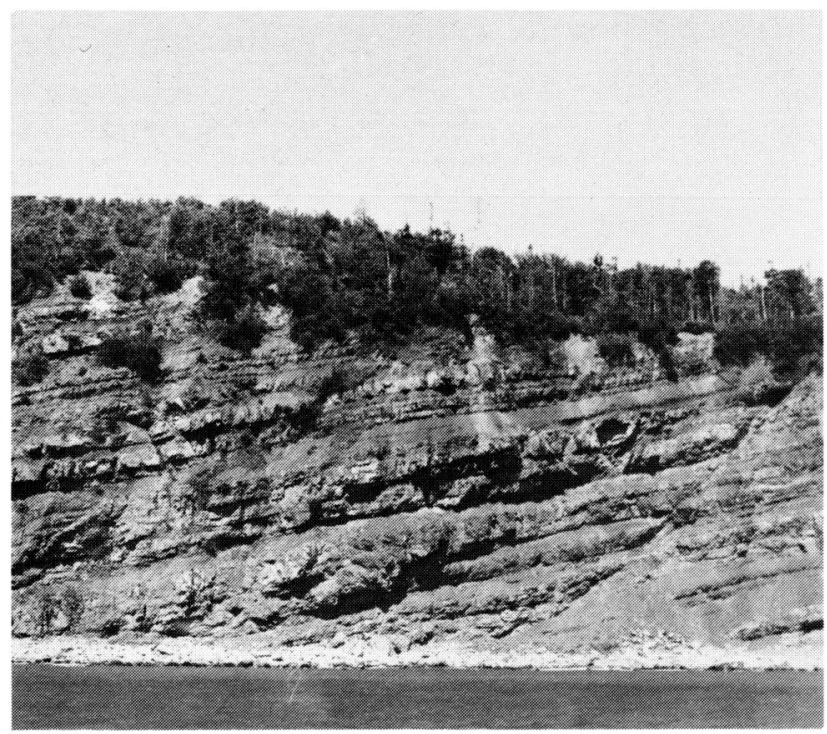

\section{RIGHT}

Fig. 14 -Coastal exposure showing abrupt thickening of a tabular sandstone into a deeply-incised channel sandbody.

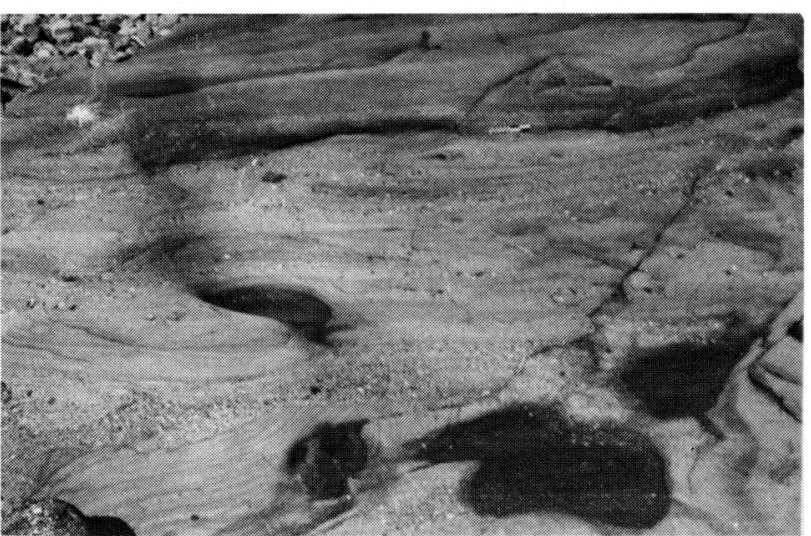

\section{LEFT}

Fig. 13 - Coastal exposure showing high lateral continuity of tabular sandstones of Facies 2.

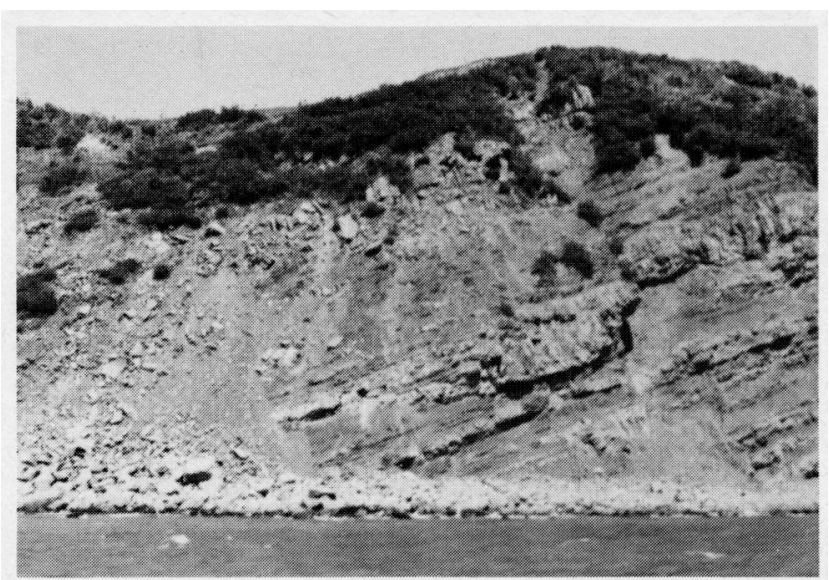

\section{LEFT}

Fig. 15-Low-angle erosion - surface at the base of a channel filled with sandstones of Facies 2 . 


\section{RIGHT}

Fig. 16 - Steep-walled and sharp-based channel, filled with Facies 2 sandstones, incised into interchannel sediments of Facies 5.

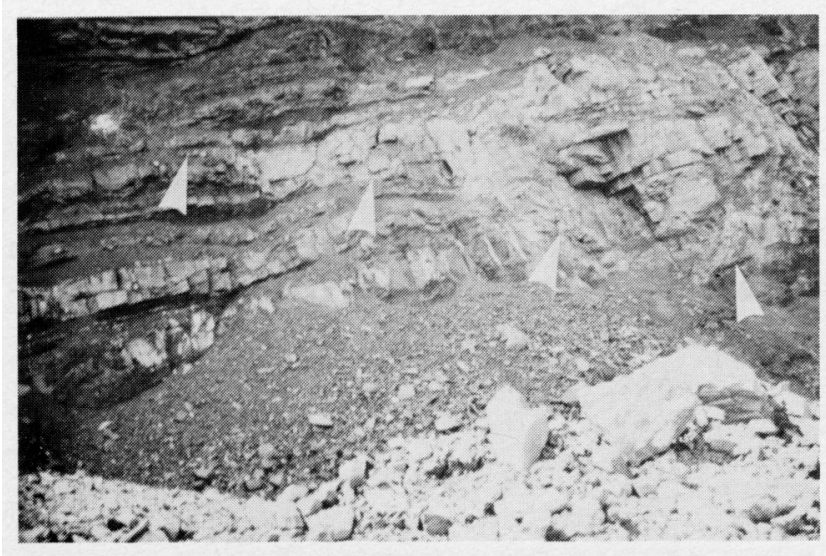

\section{RIGHT}

Fig. 20 - Thick channel sandstone (base at $105 \mathrm{~m}$, section 1) underlain by thick sequence of red, interchannel siltstones and fine sandstones of Facies 5, containing thin limestones of Facies 6 near the base.

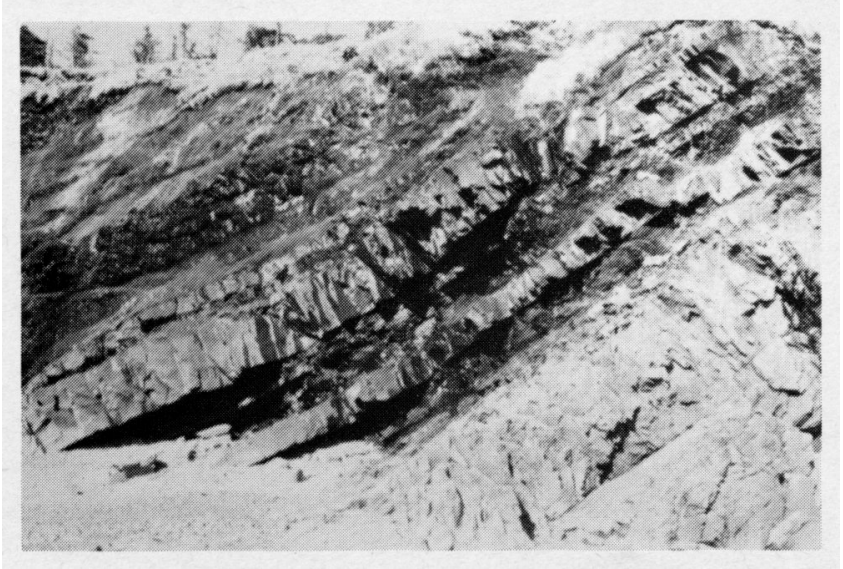

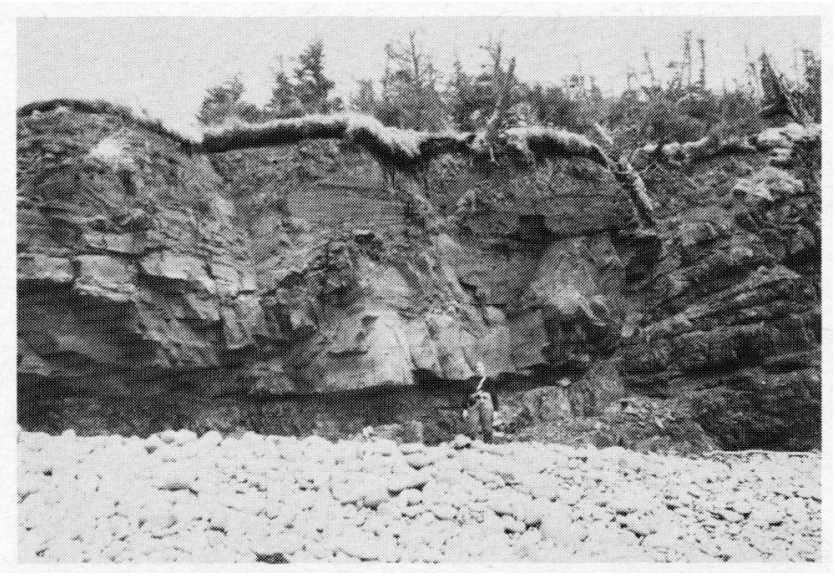

\section{LEFT}

Fig. 17 - Small channel, filled with Facies 2 sandstones, showing rapid lateral thinning $(4 \mathrm{~m}$ to $0 \mathrm{~m}$ over $6 \mathrm{~m}$ horizontally) and stepped profile of channel wall.

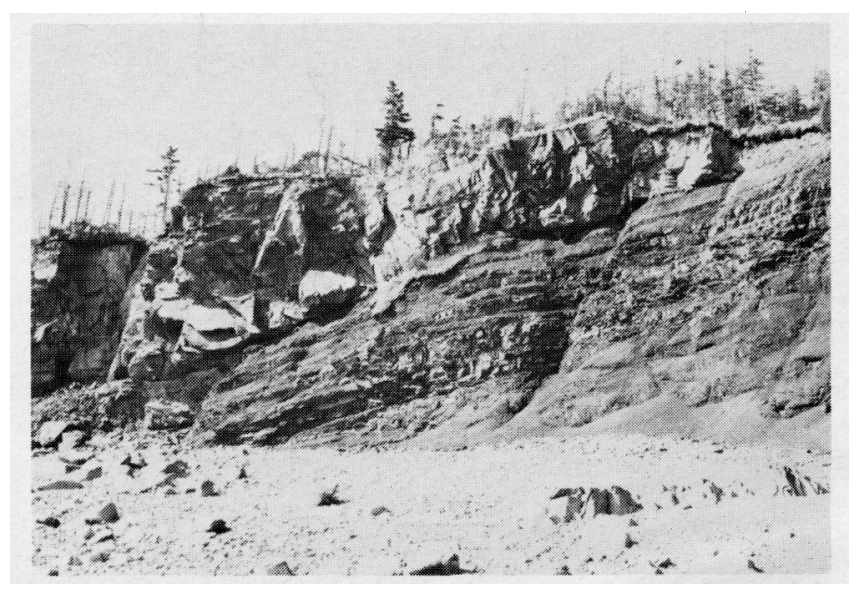

\section{LEFT}

Fig. 21 - Interbedded grey siltstones and tabular, sharp-based and graded sandstones (72-80 m, section 1$)$. Sandstones are interpreted as turbidites emplaced in an abandoned channel during floods. The upper part of the massive, channel sandstone is seen in lower right corner of picture. 
it seems likely that channelized sandstones developed on higher, more proximal parts of the alluvial fan than did tabular sandstones (cf. Bull 1972). In this position, gradients would be higher and the erosive capacity of streams greater. Channel deepening may have been initiated by periodic tectonic uplift of the fan, leading to a rejuvenation of stream profiles, causing channels to incise into their own alluvium (Blissenbach 1954, Bull 1964). The steep walls of some channels resemble those of wadis and suggest rapid channel-bank erosion and subsequent infilling. Deposition of tabular sandstones may, therefore, have been lateral to major channels during flood stage, non-channelized overbank flow, or distal to such channels, beyond the point of channel incision where flow expanded into a number of shallow, anastomosing and laterallymigrating channels (cf. Bull 1972, Steel 1974).

\section{Facies 3 - Meandering River Deposits}

Some of the lowest beds of the Tynemouth Creek Formation are visible between Giffin Pond and Rogers Head (Figs. 2 \& 19). The sediments of this section are distinct from those exposed at higher levels in the formation. They consist of yellow or grey, medium to coarse, granular sandstones which form units up to $30 \mathrm{~m}$ thick, interbedded with thick units of red siltstone (Fig. 20). Layers of small pebbles, both extra-formational (mainly quartzose) and intraformational (limestones and calcareous sandstones) are present at intervals. Four major sandstones are identified in this section. Each has a markedly erosive base which may cut down as much as $5 \mathrm{~m}$. A pebble lag is usually present at or near the base but otherwise there is no orderly grainsize change within each sandstone unit. Large scale trough and tabular cross-bedding are the principal sedimentary structures, while ball and pillow structure is also present at several horizons. Large logs of wood and smaller plant fragments are common throughout. At $22 \mathrm{~m}$ and $40 \mathrm{~m}$ in section 1 (Fig. 19), major sandstones are

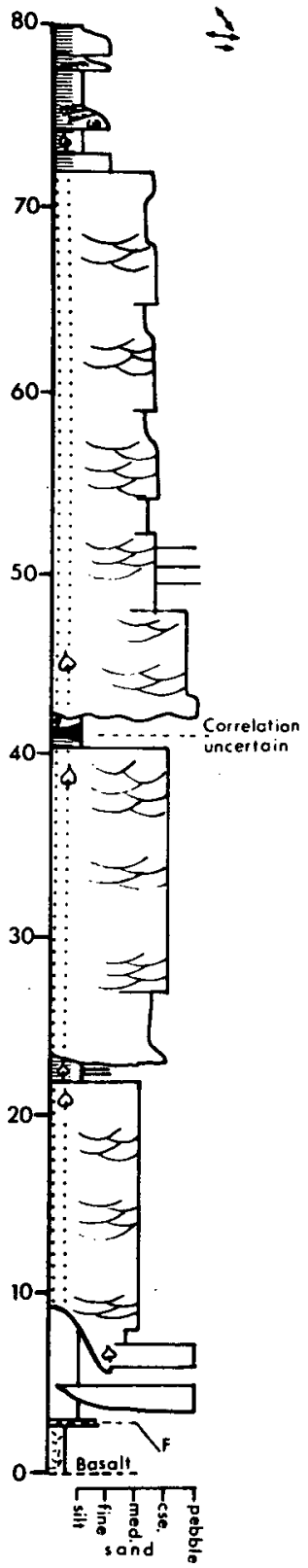

Section 1

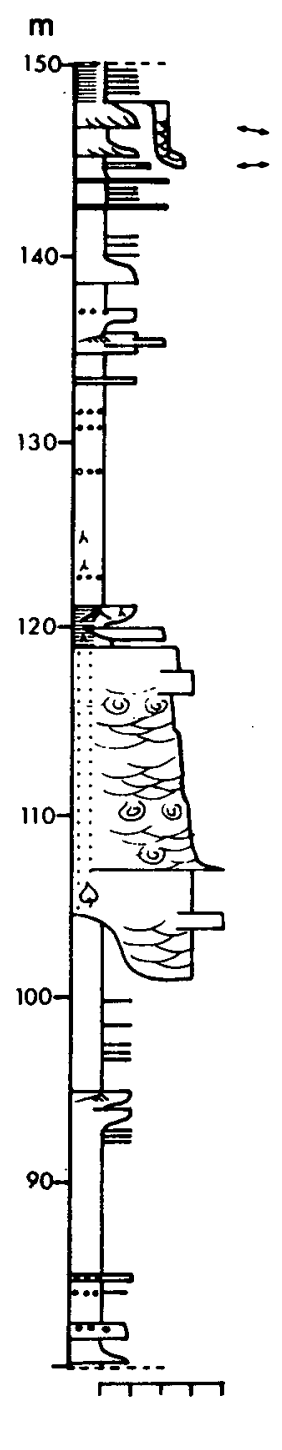

Fig. 19 - Stratigraphic section 1 measured between Giffin Pond and Rogers Head. Basalts are thrust over the overturned sediments.

separated by interbedded fine grey sandstones and carbonaceous siltstones, and at $41 \mathrm{~m}$, a lenticular, allochthonous coal is present. At $72 \mathrm{~m}$, medium-coarse sandstones are abruptly overlain by metre-bedded fine grey sandstones and laminated siltstones (Fig. 21) which persist to $80 \mathrm{~m}$. These sandstones are graded and have a sharp base upon which small flute and groove-casts are preserved. Ripples, climbing ripples, 
parallel-lamination and ball and pillow structure can be seen. Plant debris is common in both the sandstones and interbedded siltstones.

\section{Interpretation}

The sediments between $5 \mathrm{~m}$ and $80 \mathrm{~m}$ in section 1 are interpreted as the point-bar deposits of major meandering rivers. The thickness, grainsize and sedimentary structures suggest relative1y deep channels with powerful currents. The fine-grained sediments at $22 \mathrm{~m}$ and $40 \mathrm{~m}$ are interpreted as abandoned channel, levee or swale deposits. Sandstones were introduced during flooding and mud settled out during intervening periods. In this low-lying, waterlogged environment, drifted vegetable matter accumulated to form the coal at $41 \mathrm{~m}$.

The sediments between 72 and 80 mwere probably deposited in an abandoned channel to which floods periodically introduced pulses of sediment. The sharpbased sandstones in this interval have many features typical of turbidites and it is possible that flood-generated density currents were responsible for their formation. The abrupt change in the sediments at $72 \mathrm{~m}$ (Fig. 19) suggests rapid abandonment of the channel, perhaps through 'neck' cut-off (Allen 1965). Above $80 \mathrm{~m}$, there is a rapid change from grey to red, purple and green siltstones (Facies 5), which represent floodplain environments.

A fourth channel sandstone, similar in lithology to those below occurs between 101 and $119 \mathrm{~m}$ in section 1 (Fig. 19). It is capped by $3 \mathrm{~m}$ of grey sandy siltstone which encloses lenses of medium sandstone and is penetrated by abundant stigmaria and other smaller roots. These sediments grade up into structureless red and grey siltstones with calcareous nodules which are of interchannel facies 5 and lacustrine facies 6 . The sediments between 119 and $122 \mathrm{~m}$ are interpreted as levee deposits laid down adjacent to a meandering river. Levee deposits commonly contain plant roots (Fisk 1944, Coleman 1969, Ray 1976).
Facies 4 - Levee and Channel Plug Deposits

These very distinctive sediments comprise centimetre bedded fine sandstone and siltstone (Fig. 22). Sandstones are usually between 1 and $5 \mathrm{~cm}$ thick and have a sharp, slightly erosive base and gradational top. They may be structureless, ripple or plane-laminated. The interbedded siltstones are structureless and usually grey. Numerous sandstone stem-casts of Calamites are typical of this facies. The stems are often many tens of centimetres long, oriented approximately normal to bedding and are evidently in growth position (Fig. 23). This facies always occurs in close association with channel sandstones. Usually it overlies the sandstone with a gradational contact (eg. Section 3, 118-120 m, Section 4, 367-369.5 m). Occasionally however, lenticular bodies of Facies 4 are either enclosed within a channel sandstone or conglomerate (eg. section $3,98 \mathrm{~m}$, where a channel-shaped lens is $11 \mathrm{~m}$ wide and $1.7 \mathrm{~m}$ thick, section 4, 567-568 m, 573-577 m, Fig. 24). or 1ie immediately below and are erosively overlain by channel deposits (eg. section 2, 50-53 m, section 3, 174-176 m, Fig. 25).

\section{Interpretation}

When Facies 4 gradationally overlies channel sandstones, it most probably represents a levee or swale environment of which thinly-interbedded sandstones and siltstones are typical (Fisk 1944, Jahns 1947, Schumm and Lichty 1963, Allen 1965, Jackson 1976, Ray 1976). Each sandstone-siltstone couplet represents a flood event. A levee interpretation is strengthened by the occasional presence of slumped blocks of Facies 4 within channel sandstones of Facies 2 (Fig. 26).

Lenticular units of Facies 4, occurring above, within or below coarsegrained channel deposits are best interpreted as the fillings of abandoned channels. As with levees, deposition took place mainly during floods. The abundance of in situ Calamites indicates 
favorable growth conditions, and in particular suggests a high ground-water table. The evidevce suggests that growth of the plants kept pace with slow and relatively low-energy sedimentation for ? many years, during which the lower parts of the plant stems were buried to a depth of a metre or more.

When Calamites-bearing units of Facies 4 are abruptly overlain by massive channel or sheetflood sandstones of facies 2 or 5, Calamites stems often project into the massive sandstones for up to $50 \mathrm{cms}$ (Fig. 23). This suggests that stands of plants were eventually overwhelmed by a rapid influx of sediment and that the higher portions of the stem were destroyed either by breakage or decay.

Facles 5 - Interchanne1 and Distal Fan Deposits

Interchannel sediments are characterized by a red colour, fine grainsize and 1aterally-extensive beds (Fig. 27). Sediments consist of red siltstone which sometimes contains rootlets and small calcium carbonate nodules, interbedded with fine sandstone. Bedding may be on a millimetre, centimetre or decimetre scale, the latter being the most common. Sandstones are often silty and appear massive although ripples or cross-bedding are sometimes visible. Significant channeling is absent. Decimetre-bedded sandstones are usually sharp-based with tops gradational to siltstone. Quite commonly, upright Calamites stem casts are present in the lower parts of these sandstones (Fig. 23).

Well-developed thickening-up sequences are sometimes seen, the lowest beds of which may be grey and enclose a laminated carbonaceous siltstone or very thin coal (Fig. 28). Thickening-up sequences may be overlain by sandstones of Facies 2.

Paleosols are a distinctive component of this facies. They are usually structureless and characterized by a bleached, pale grey or green colour. Paleo- sols are most commonly developed on the top of Facies 2 sandstones (eg. section $2,74 \mathrm{~m}$; section $3,12 \mathrm{~m}, 21 \mathrm{~m}, 445 \mathrm{~m}$, etc.) and usually have a well-1ithified, irregular top surface, often pitted by molds of Calamites stems and small roottubes (Fig. 29). On occasion, they are overlain by a very thin coal.

In other instances, a paleosol may be developed in a siltstone at the top of an upward-fining sequence (eg. section $2,49 \mathrm{~m}$; section $4,507 \mathrm{~m} ; 514 \mathrm{~m}$ ). In exceptionally thick and well-developed examples (eg. section 4, $514 \mathrm{~m}$ ), long, green-coloured 'tubes' (roots? or burrows?, Allen 1974) penetrate red siltstone to a depth of over $1 \mathrm{~m}$ (Fig. 30).

\section{Interpretation}

Sediments of Facies 5 are comparable to interchannel and distal fan sediments described from the Devonian of Scotland (Wilson 1980) and the Upper Carboniferous of Spain (Heward 1978). Siltstones clearly represent a low-energy environment that may have been either lateral or distal to channels, in which deposition from suspension occurred during periods of flooding. The interbedded sandstones are interpreted as sheetflood deposits (McGee 1897, Davis 1938, Blissenbach 1954, Heward 1978, Tunbridge 1981). The thickness of each sandstone sheet probably reflects both the distance from the source area and the magnitude of individual floods. The common occurrence of in situ calamites, particularly in the thicker and often massive sheet sandstones suggests a very high instantaneous rate of sedimentation. Thickening-upward sequences may be interpreted as the result of fan lobe progradation, during which progressively greater volumes of sediment were supplied to the area fronting the lobe (Heward 1978).

Paleosols developed in vegetated areas when rates of erosion and sedimentation were very low and pedogenic processes were able to modify the sediment. The common occurrence of paleosols as cappings to sheetflood and, more commonly, channel sandstones (Facies 2), 
probably reflects the construction and eventual abandonment of a fan lobe. This localized sedimentation resulted in both slight topographic elevation, and improved drainage. The former condition would tend to divert subsequent flows into adjacent, low-1ying areas, thus reducing the sedimentation rate on the lobe surface, providing a stable environment for plant growth. Improved drainage would promote leaching and the development of an illuviated soil profile. The scarcity of coals above paleosols suggests that either vegetation was insufficiently luxuriant for coal genesis, or, perhaps more likely, free drainage and oxidation destroyed much of the vegetable matter before significant accumulation could occur. The grey or green colour of paleosols suggests the presence of reduced iron compounds, the genesis of which was probably related to bacterial activity in the presence of organic matter.

Paleosols developed in siltstones are similarly indicative of low sedimentation rates and probably formed on longabandoned sectors of the fan, far from active distributary channels.

Calcite nodules are present in siltstones of this facies (eg. section 4, $176 \mathrm{~m})$ but are rare in those parts of the sequence dominated by Facies 1 and 2 (conglomerates and sandstones). Only in the thick siltstone sequences of Section 1 are these nodules common (eg. section 1, 80-85 m, 128-137 m). Calcite nodules are common in soils that are subject to strong, seasonal surface evaporation leading to carbonate supersaturation and subsequent precipitation within the soil profile (Reeves 1970).

The nodules in Facies 5 are comparable to those in Devonian alluvial sediments (Friend and Moddy-Stuart 1970) which were thought to represent a welldrained soil and are generally considered to be an early form of caliche (Gile et al. 1966, Aristarain 1971, Allen 1974, Wilson 1980). The ideal climate for caliche formation is neither arid nor humid, the essential condition being one of clearly separate wet and hot, dry seasons (Reeves 1970). Suich a seasonal distribution of rainfall may be reflected in the Tynemouth Creek Formation in the overall pulsatory or ephemeral style of sedimentation. The relative scarcity of nodules in siltstones interbedded with Facies 1 and 2 may, in large part reflect inhibition by a relatively high sedimentation rate (Leeder 1975) on the more proximal part of the fan.

\section{Facies 6 - Bioclastic Limestones}

Bioclastic limestones are a rare but distinctive component of the Tynemouth Creek Formation. Three principal occurrences of limestone are known and two distinct types, $A$ and $B$ are recognized.

Type A, Shelly Limestone - In section 1 , two limestones are present at 124 and $128 \mathrm{~m}$. Both examples are about 5 cm thick, nodular and enclosed in red siltstone. These two limestones have a micritic matrix and are dominated by a fauna of ostracodes, the valves of which are often articulated and may have a geopetal fill, together with common Spirorbis tubes and rare gastropods. Burrows containing faecal pe1lets replaced by sparry calcite are also seen (Fig. 31).

In section 3 , between $65-67 \mathrm{~m}$, several $2-5 \mathrm{~cm}$ thick yellowish-weathering dark, ?organic-rich shelly limestones are present towards the top of a relatively thick sequence of distal fan siltstones and sandstones (Facies 5). The fauna is dominated by small ostracodes which have a distinctive ribbed shell ornament, a few small turreted gastropods are also present.

Type B, Algal Limestone - In section 2 , at $99 \mathrm{~m} \mathrm{a}$ nodular, sandy limestone up to $15 \mathrm{~cm}$ thick directly overlies a sandstone of Facies 2. This limestone is apparently unique in the Tynemouth Creek Formation and consists of laminated algal plates which may show an oncolitic structure. These are distributed through a sandy matrix which also contains rare, ostracode and gastropod fragments (Fig. 32). 


\section{RIGHT}

Fig. 22 - Thinly-interbedded siltstone and sandstone of Facies 4. Sandstones are sharp and slightly erosive-based and grade up into siltstone. They are interpreted as levee sediments and overlie massive channel sandstones of Facies 2 , seen in lower right.
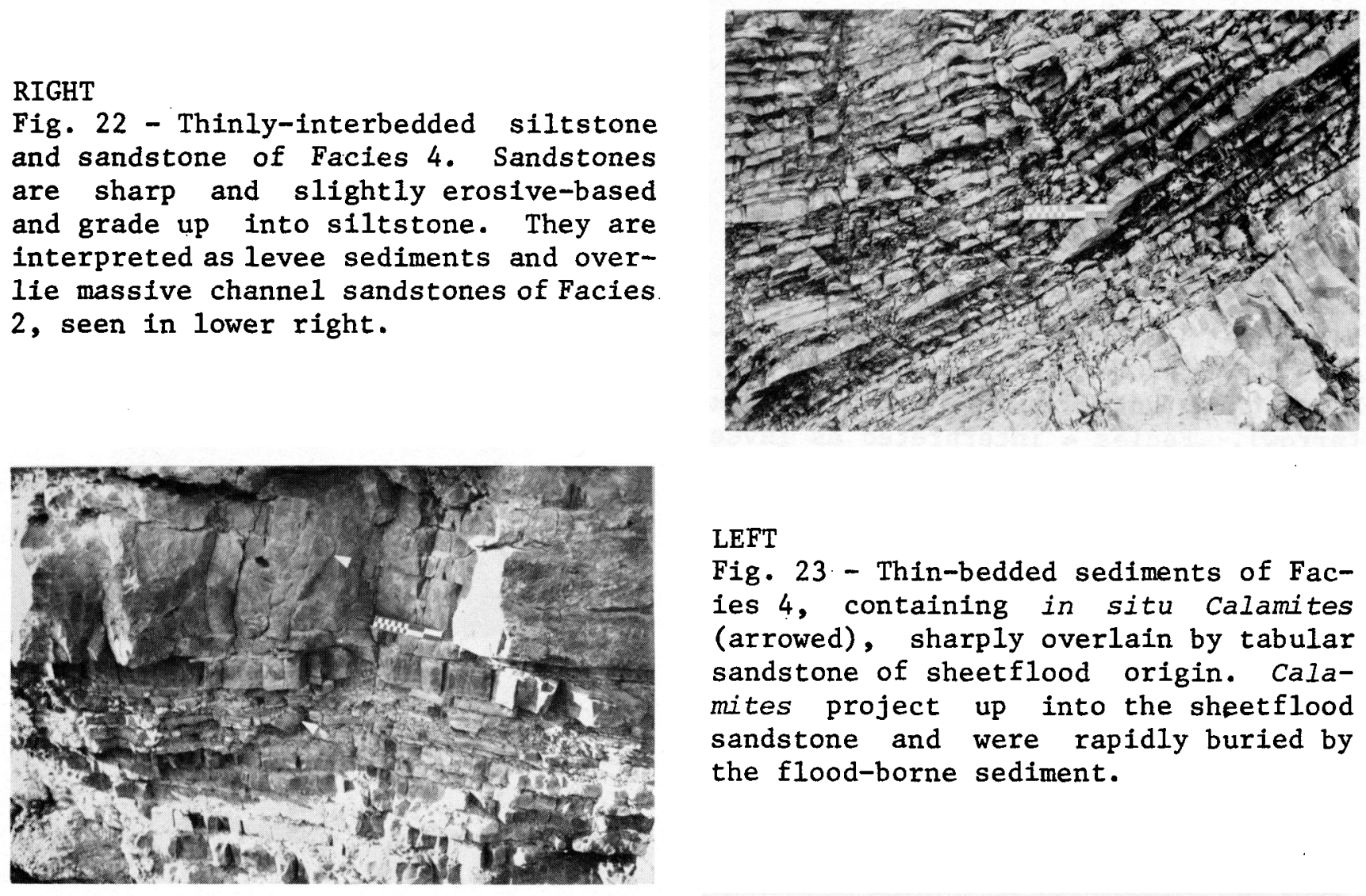

\section{LEFT}

Fig. 23 - Thin-bedded sediments of Facies 4, containing in situ Calamites (arrowed), sharply overlain by tabular sandstone of sheetflood origin. Calamites project up into the sheetflood sandstone and were rapidly buried by the flood-borne sediment.

\section{RIGHT}

Fig. 24 - Facies 4 interbedded with streamflood conglomerates. In this example, the thin-bedded sediments are interpreted as the fill of an abandoned channel.
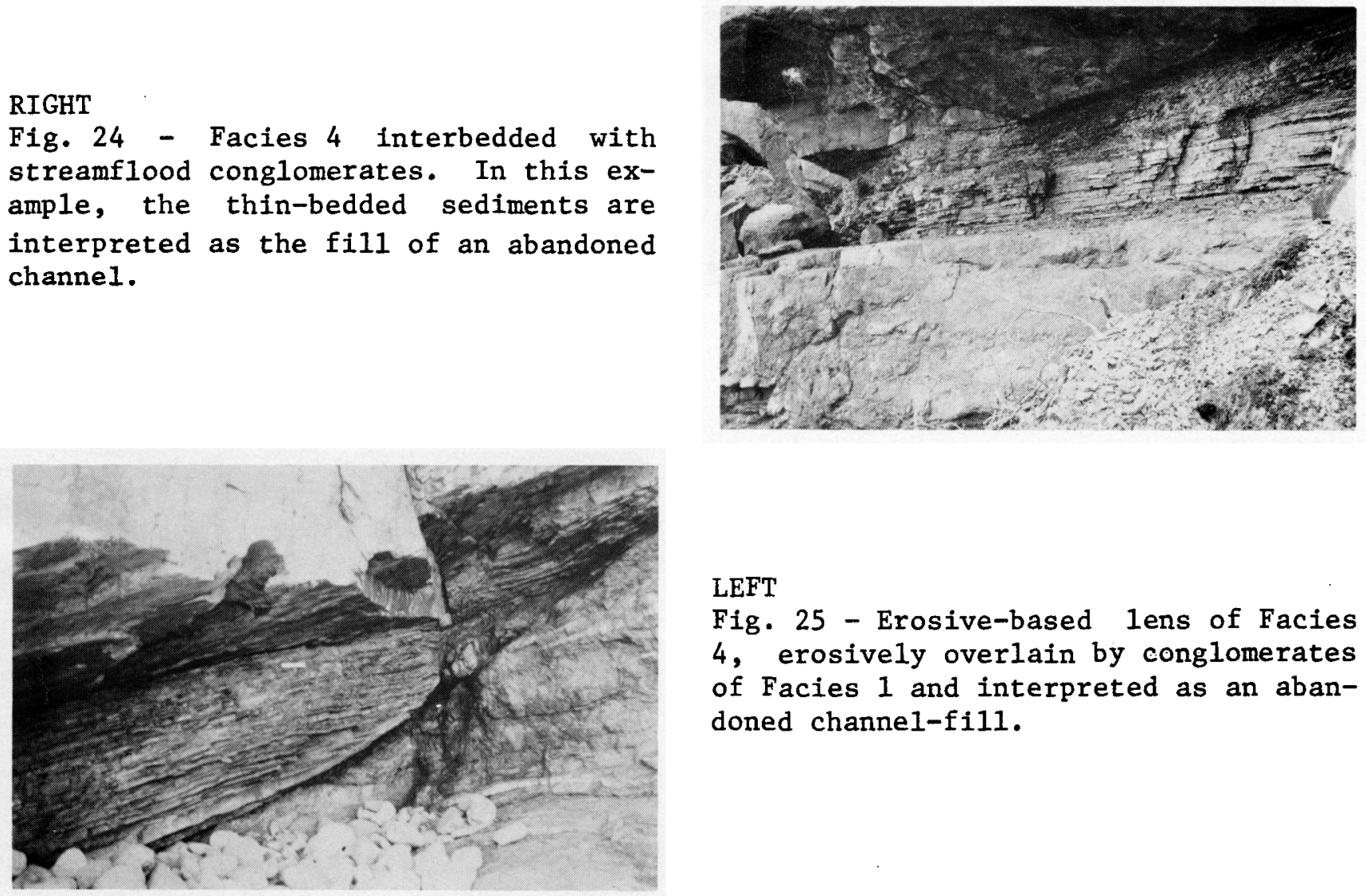

LEFT

Fig. 25 - Erosive-based lens of Facies 4, erosively overlain by conglomerates of Facies 1 and interpreted as an abandoned channel-fill. 
RIGHT

Fig. 26 - Slumped block of Facies 4 enclosed within sandstones of Facies 2. Note sharp, curved base to slumped block (arrow). Facies 4 interpreted as levee sediments which subsequently slumped into the channel.

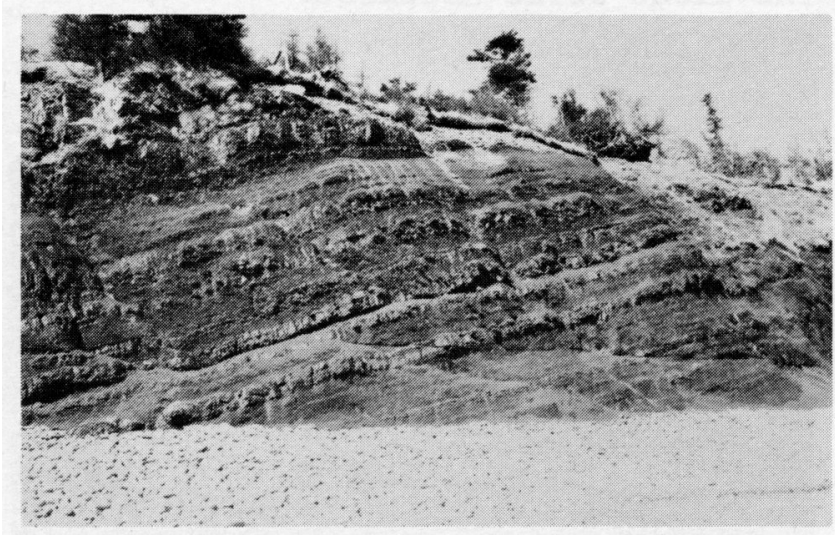

RIGHT

Fig. 28 - Thickening-upward sequence in Facies 5. Sequence begins at a very thin coal (at level of figures waist) overlain by progressively thicker-bedded fine and medium sandstones.

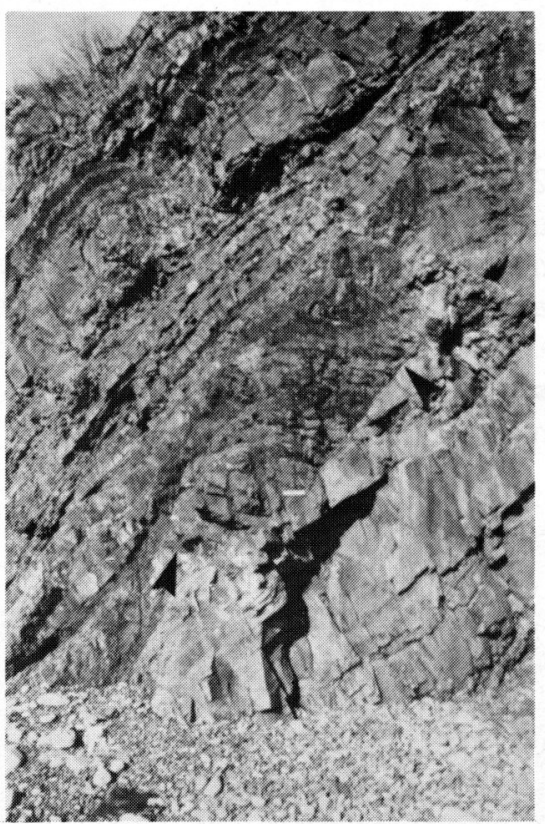

LEFT

Fig. 27 - Facies 5, interchannel sediments showing high lateral continuity of sheet sandstones, interbedded with red siltstones.

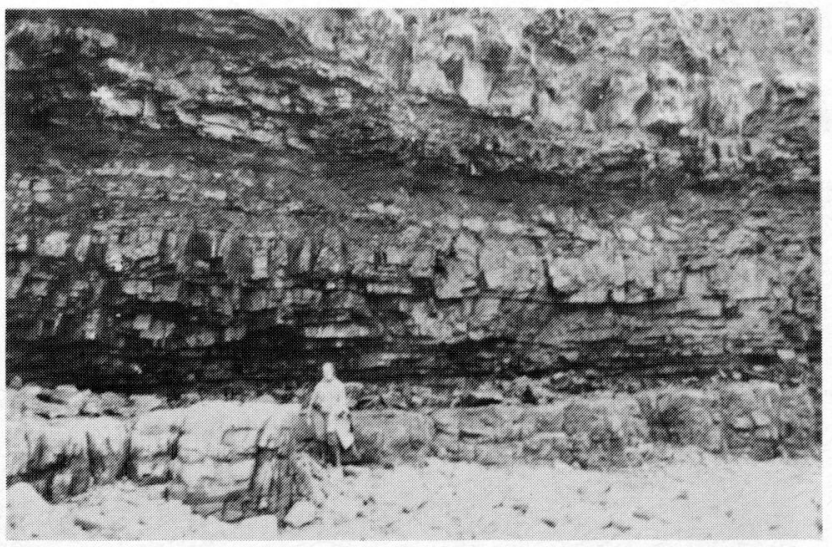




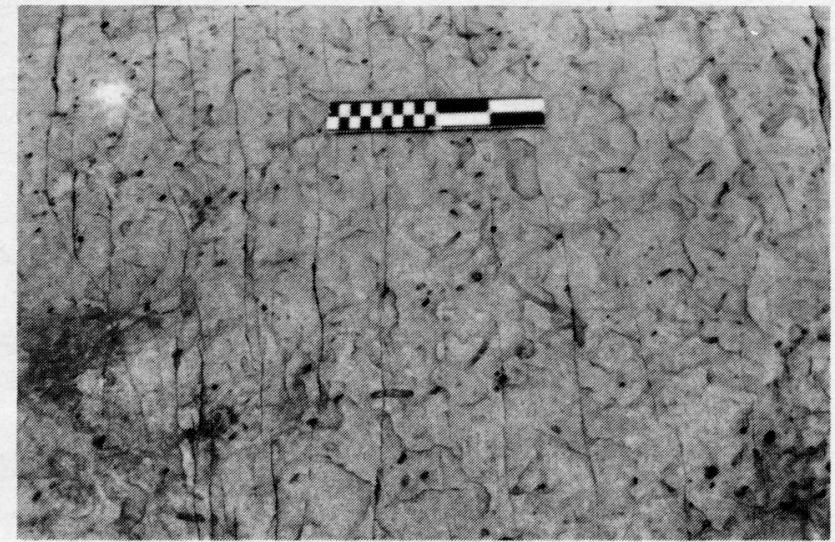

RIGHT

Fig. 30 - Thick red siltstone with welldeveloped, green-stained ?root tubes, erosively overlain by a channel sandstone of Facies 2.

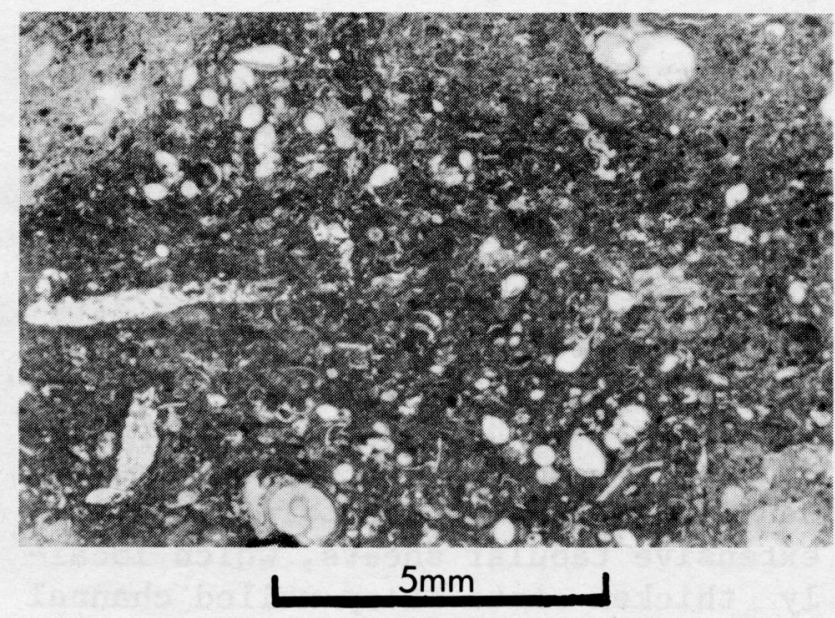

Fig. 32 - Algal 1imestone of Facies 6 (Section 2, $99 \mathrm{~m}$ ). Note laminated calcareous plates constructed by Phylloid algae in a matrix of angular sand grains.

\section{LEFT}

F g. 29 - V w of top urfac of Facies 2 sandstone showing numerous root tubes within a bleached, bioturbated palaeosol.

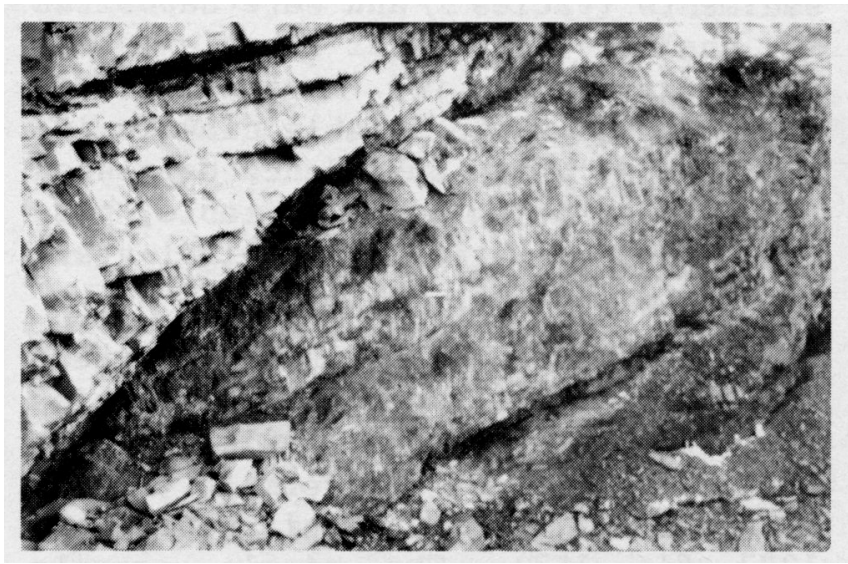

Fig. 31 - Bioclastic limestone of Facies 6 (Section 1, $123 \mathrm{~m}$ ) composed of numerous articulated ostracodes, small gastropods and bivalves. Note pelletfilled burrows.

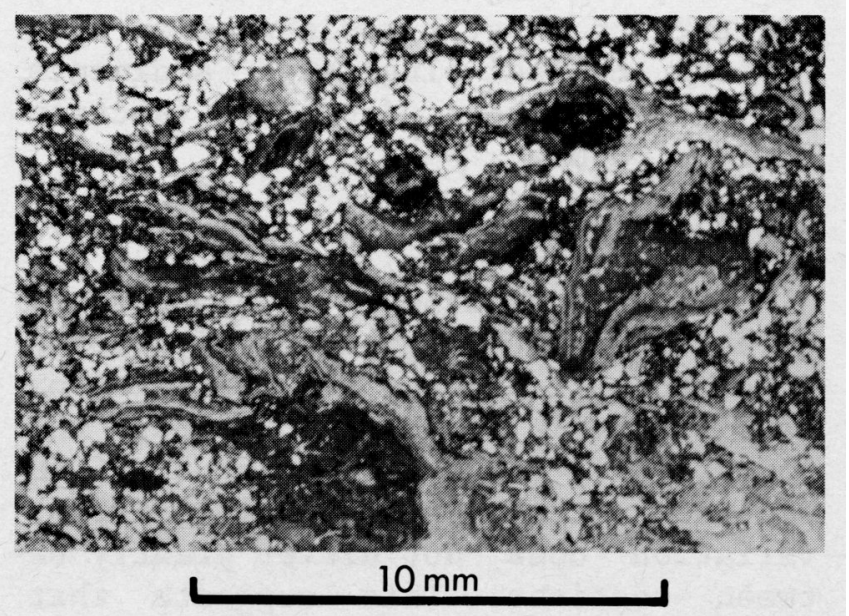


Interpretation - Limestones comparable to Type $A$ have been described from Devonian and Carboniferous alluvial sequences (Friend and Moody-Stuart 1970, Heward 1978). The former described marlstones with a micritic matrix, thought to be of charophyte origin, containing myriad ostracode valves. These marlstones were interpreted as the deposits of flood plain lakes that were starved of clastic sediment. Both examples of Type A limestones occur in thick units of interchannel distan fan sediments (Facies 5 ) and were deposited in shallow freshwater lakes existing in areas that, for ?several tens of years lacked an appreciable clastic input, during which subsidence depressed the surface below the water table, permitting colonization by an algal-grazing fauna.

The laminated algal plates of Type B limestone may be ascribed to a species of Phylloid algae, comparable examples being known from the Permian (Flugel 1977, p1. 1) and Carboniferous (Wray 1977, fig. 157). The single example of Type B in the Tynemouth Creek Formation appears to have developed in an abandoned but water-filled channel which, after abandonment, received no clastic input and colonization by calcareous algae took place. The disappearance of ostracodes and gastropods in the upper part of the limestone suggests an increasingly hostile environment and perhaps reflects stagnant, anoxic conditions. After a period of time, the algae were overwhelmed by a return to clastic sedimentation when typical channel-plug/levee sediments of Facies 4 were deposited (section $2,100-101 \mathrm{~m})$.

\section{Palaeocurrents}

Wherever possible, palaeocurrents were measured throughout the Tynemouth Creek Formation, and their directions are shown in Fig. 33. Although the formation is, exposed over about $16 \mathrm{~km}$ of coast, the range of palaeocurrent variation does not differ greatly between sections. This suggests that the Tynemouth Creek Formation represents a sector of a large fan, having its apex some distance to the southeast of the study area. The palaeocurrent pattern is closely comparable to that measured in other ancient alluvial fan deposits (cf. Williams 1966; Howard 1966; Nilsen 1968, 1969; Co1linson 1972; Morton 1979; Wilson 1980).

Summary of Conclusions

The Tynemouth Creek Formation of southern New Brunswick is an alluvial sequence of Lower Pennsylvanian (probably Westphalian B) age. It locally overlies basalts of uncertain (?Precambrian, ?Devonian age. Local patches of Precambrian rocks are exposed inland suggesting a basal landscape unconformity. In the main, however, the formation is fault-bounded. The Tynemouth Creek Formation has a minimum thickness of about $800 \mathrm{~m}$, and is probably considerably thicker. The formation was deposited in an alluvial fanpiedmont setting and shows an overall upward-coarsening.

Six principal sedimentary facies are recognized. Coarse polymict streamflood conglomerates (Facies 1) predominate at the top of the sequence and represent the most proximal, nearsource deposits preserved in the area. The immaturity and size of the clasts suggests a source only a few kilometres distant. Braided river deposits (Facies 2) comprise coarse to medium pebbly sandstone which form laterallyextensive tabular sheets, which local1y thicken into steep-walled channel sandbodies up to $8 \mathrm{~m}$ thick. Tabular sandstones were deposited in shallow unstable channels that continually migrated over the fan surface, generating thin, tabular sandbodies. Channelized sandstones which are more common in the upper part of the fan sequence, record localized incision by (?major) channels, perhaps related to tectonic rejuvenation of streams on the upper part of the fan.

In the lowest part of the formation, coarse, erosive-based sandstones (Fac- 

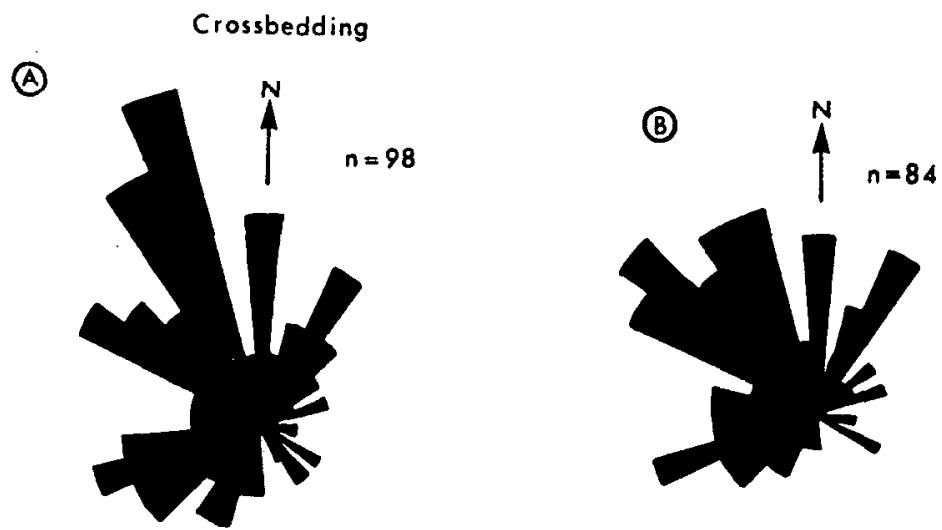

(C)
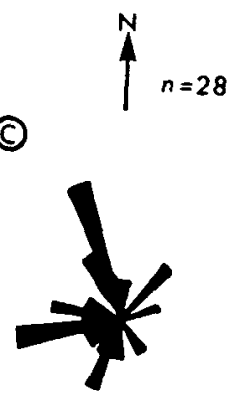

(D)
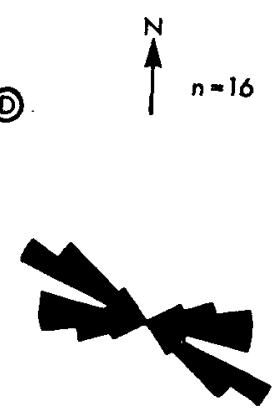

Fig. 33 - Palaeocurrent rose diagram for Tynemouth Creek Formation. Fig. A shows all cross-bedding directions. B shows Sections 2 and 3 , all readings. C shows Section 4, all readings. D shows all bidirectional readings (grooves, channels, etc.). Note unimodal distribution with vector mean directed towards the north-west.

ies 3), $15-30 \mathrm{~m}$ thick alternate with interchannel siltstones. These thickbedded, relatively massive sandstones are quite distinct from braided-river sediments of Facies 2 and are interpreted as point-bar deposits of major meandering rivers. Abandoned channel, levee and crevasse splay deposits are assoclated with these thick sandstones and lend support to a meandering river interpretation. These major rivers are thought to have flowed eastward on a low-lying alluvial plain lying to the north of a basin-margin alluvial fan.

Braided river and streamflood deposits are often associated with relatively thin units of thinly-bedded sandstone and siltstone (Facies 4) which usually contain in situ Calamites stems. These deposits represent proximal overbank/ levee and abandoned channel environments, all of which were favourable sites for the growth of dense stands of Calamites.
In interchannel and distal fan areas, red siltstones and tabular fine sandstones (Facies 5) were deposited. Siltstones may have been deposited from floodwaters or as wind-blown dust while tabular sandstones were the result of sheet flooding. Thickening-up sequences of siltstone and sandstone are interpreted as prograding fan lobes. Siltstones, particularly those assoclated with meandering river sandstones contain small calcite nodules which are interpreted as immature caliche and suggest a distinctly seasonal climate. Rooted palaeosols are a common feature of interchannel sediments. Many developed on the top of braided river sandstones after channel abandonment. The slight topographic elevation of the channel area inhibited further sedimentation promoting vegetation growth and soil development.

Thin bioclastic (ostracode/gastropod/spirorbis) limestones (Facies 6) 
are occasionally present in thick siltstone sequences and represent alluvialplain lakes that developed in areas starved of clastic sediment. A single algal limestone was identified and probably formed in an abandoned channel of a braided river.

Palaeocurrents have a unimodal, fanlike distribution with a mean flow towards the north-west. This pattern compares closely with that of other ancient alluvial fan sequences.

Regional considerations suggest that the Tynemouth Creek Formation was deposited on a major alluvial fan that built northward from the southern, ?fault-bounded margin of the Cumberland Basin. Rapid subsidence of this basin occurred during early Lower Pennsylvanian times, probably in response to an extensional tectonic regime, perhaps associated with wrench-faulting on the Cobequid Fault. Preliminary studies of pebble provenance indicate a possible source region in the western Cobequid Highlands (H. Donohoe, pers. com.).

The upward coarsening of the Tynemouth Creek Formation is interpreted as evidence of source-area uplift through progressively accelerating basin-margin faulting (cf. Steel and Wilson 1975), resulting in a progradation of the fan causing deposition of progressively coarser, upper-fan gravels over finer-grained, lower-fan sediments.

In general, sedimentation on the fan seems to have been episodic with streamfloods, sheetfloods and braided rivers transporting and depositing sediment only during relatively short-lived periods of flood runoff. Braided rivers, perhaps sourced from springs may have carried water at low stage for longer periods but effected little sediment transport.

The sedimentary evidence as a whole (sediment transport processes, calcretes, redbeds) suggests a seasonal climate of alternating hot, dry and rainy perlods (Gile et al. 1966, Walker 1967, Reeves 1970, Woodrow et al. 1973).

\section{ACKNOWLEDGEMENTS}

G. Plint would like to express particular thanks to the Ewing family of Tynemouth Creek who did so much to make him welcome. The hospitality of Pat and Beverley Franklin, Mr. and Mrs. G. Chatterton, Mr. and Mrs. H. Greer, Mr. and Mrs. W. Greer and Mr. and Mrs. E. Maynard was very much appreciated. Alec Moore and his boat made possible a photographic survey of the coast. Sedley Barss made palynological analyses of our samples, Gary Vasey provided valuable discussion on the limestones and their faunas, Howard Donohoe kindly examined the pebble suite and SamanthaJame Mugridge assisted with field photography. Financial support was provided by a U.N.B. postdoctoral fellowship to G. Plint, while H.W. van de Poll acknowledges an N.S.E.R.C. operating grant No. A9033. We would like to thank Ancel Murphy and Miles Thompson for preparation of thin sections, Catherine Orchard and Sherri Townsend, for typing the manuscript. The paper was refereed by Drs. P.F. Friend and H.G. Reading who we thank for their constructive criticism.

ALCOCK, F. J. 1938. Geology of Saint. John region, New Brunswick. Geological Survey of Canada, Memoir 216.

ALLEN, J. R. L. 1965. A review of the origin and characteristics of Recent alluvial sediments. Sedimentology, 5, pp. 89-191.

1974. Studies in filuviatile sedimentation: implications of pedogenic carbonate units, Lower 0ld Red Sandstone, Anglo-Welsh outcrop. Geological Journal, 9, pp. 181-208.

ALLEN, J.R.L. and WILLIAMS, B.P.J. 1979. Interfluvial drainage on Siluro-Devonian alluvial plains in Wales and the Welsh Borders. Journal of the Geological Society of London, 136, pp. 361366.

ARISTARAIN, L. F. 1971. On the definition of caliche deposits. Zeitschrift fur Geomorphologie, 15, pp. 274-289. 
BAILEY, L.W. 1865. Observations on the geology of southern New Brunswick. Printed by order of the House of Assembly, Fredericton. 158 p. 1 Map and Sections.

BAILEY, L.W. and MATTHEW, G. F. 1918. Some problems of New Brunswick Geology. Transactions of the Royal Society of Canada, Series III, 12, pp. 105-130.

BELL, W. A. 1927. Outline of Carboniferous stratigraphy and geologic history of the Maritime Provinces of Canada. Transactions of the Royal Society of Canada, Series III, 21, pp. 75-108.

BELT, E.S. 1968. Carboniferous continental sedimentation, Atlantic Provinces, Canada. Geological Society of America, Special Paper 106, pp. 127176.

BLISSENBACH, E. 1954. Geology of alluvial fans in semi-arid regions. Bulletin of the Geological Society of America, 65, pp. 175-190.

BLUCK, B.J. 1965. The sedimentary history of some Triassic conglomerates in the Vale of Glamorgan, South Wales. Sedimentology, 4, pp. 225-245.

1967. Deposition of some Upper 01d Red Sandstone conglomerates in the clyde area: A study in the significance of bedding. Scottish Journal of Geology, 3, pp. 139-167.

BULL, W.B. 1964. Alluvial fans and near-surface subsidence in Western Fresno County, California. United States Geological Survey Professional Paper, 437A, 71 p.

BULL, W.B. 1972. Recognition of alluvial fan deposits in the stratigraphic record. In: J.K. Rigby \& W. K. Hamblin (Eds.) Recognition of ancient sedimentary environments. Society of Economic Palaeontologists and Mineralogists, Special Publication, 16, pp. 63-83.

COLEMAN, J.M. 1969. Brahmaputra River: channel processes and sedimentation.
Sedimentary Geology, 3, pp. 129-139.

COLLINSON, J. D. 1972. The Rode $\emptyset$ Conglomerate of Inner Scoresby Sund and the Carboniferous (?) and Permian rocks west of the Schuchert Flod. Meddelelser om Gronland, Bd. 192, No. 6, pp. 1-48.

DAVIS, W. M. 1938. Sheetfloods and streamfloods. Bulletin of the Geological Society of America, 49, pp. 1337-1406.

DENNY, C.S. 1965. Alluvial fans in the Death Valley region, California and Nevada. United States Geological Survey, Professional Paper, 466, 62p.

EISBACHER, G. H. 1970. Contemporaneous faulting and clastic intrusions in the Quirke Lake Group, Elliot Lake, Ontario. Canadian Journal of Earth Sciences, 7, pp. 215-225.

ELLS, R. W. 1907. The geology and mineral resouces of New Brunswick. Department of Mines, Geological Survey Branch, Ottawa, 135p. 1 map.

FISK, H.N. 1944. Geological investigation of the alluvial valley of the lower Mississippi River. Mississippi River Commission, Vicksburg, 78p.

FLUGEL, E. 1977. Environmental models for Upper Palaeozoic benthic calcareous algal communities. In: Fossil Algae, recent results and developments. Edited by E. Fluge1. Springer Verlag, pp. 314-343.

FRIEND, P.R. and MOODY-STUART, M. 1970. Carbonate deposition on the river floodplains of the Wood Bay Formation (Devonian of Spitzbergen). Geological Magazine, 107, Pp. 181-195.

GILE, L.H., PETERSON, F.F. and GROSSMAN, R.B. 1966. Morphologic and genetic sequences of carbonate accumulation in the desert soils. Soll Science, 101, pp. 347-360.

GLOPPEN, T.G. and STEEL, R.H. 1981. The deposits, internal structure and geometry in six alluvial fan - fan delta bodies (Devonian-Norway). A study in the significance of bedding sequences 
in conglomerates. In: Recent and ancient aonmarine depositional environments: Models for exploration: Edited by F. G. Ethridge and R.M. Flores. Society of Economic Palaeontologists and Mineralogists, Special Publication 31, pp. 49-69.

HARMS, J.C. 1965. Sandstone dikes in relation to Laramide faults and stress distribution in the southern Front Range, Colorado. Bulletin of the Geological Society of America, 76, pp. 981-1001.

HAYES, A.0, and HOWELL, B.F. 1937. Geology of Saint John, New Brunswick. Geological Society of America, Special Paper, 5, 146p.

HEWARD, A.P. 1978. Alluvial fan and lacustrine sediments from the Stephanian A and B (LaMagdalena, Cinera-Matallana and Sabero) coalfields, northern Spain. Sedimentology, 25, pp. 451-488.

HOWARD, J.D. 1966. Patterns of sediment dispersal in the Fountain Formation of Colorado. Mountain Geologist, 3, pp. 147-153.

JACKSON, R.G. 1976. Depositional model of point bars in the Lower Wabash River. Journal of Sedimentary Petrology, 46, pp. 579-594.

JAHNS, R.H. 1947. Geologic features of the Connecticut Valley, Massachusetts, as related to recent floods. United States Geological Survey, Water Supply Paper, 996, pp. 1-158.

KELLY, D.G. 1967. Some aspects of Carboniferous stratigraphy and depositional history in the Atlantic Provinces. In: Geology of the Atlantic Region, Edited by R.W. Neale and H. Williams, Geological Association of Canada, Special Paper 4, pp. 213-228.

LAJTAI, E.Z. and STRINGER, P. 1981. Joints, tensile strength and preferred fracture orientation in sandstones, New Brunswick and Prince EdWard Island, Canada. Maritime Sediments and Atlantic Geology, 17, pp. 70-87.
LEEDER, M.R. 1975. Pedogenic carbonate and flood sediment accretion rates: a quantitative model for alluvial, arid zone 1ithofacies. Geological Magazine, 112, Pp. 257-270.

MARSCHALKO, R. 1965. Clastic dikes and their relations to syn-sedimentary movements (Flysch of central Carpathians). Geologicke prace, 36, pp. 139-148.

MCGEE, W.J. 1897. Sheetflood erosion. Bulletin of the Geological Society of America, 8, pp. 87-112.

McGOWEN, J.H. and GROAT, C.G. 1971. Van Horn Sandstone, west Texas: An alluvial fan model for mineral exploration. University of Texas at Austin, Bureau of Economic Geology Report of Investigations, $72,57 \mathrm{p}$.

MORTON, D.J. 1979. Palaeogeographical evolution of the Lower Old Red Sandstone basin in the western Midland Valley. Scottish Journal of Geology, 15, pp. 97-116.

NILSEN, T.H. 1968. The relationship of sedimentation to tectonics in the Solund Devonian district of southwestern Norway. Norge geologiske Undersokelse, 259, 108p.

1969. 01d Red sedimentation in the Beulandet-Vaerlandet Devonian District, western Norway. Sedimentary Geology, 3, pp. 35-57.

PETERSON, G.L. 1966. Structural implications of sandstone dikes, Northwest Sacramento Valley, California. Bulletin of the Geological Society of America, 77, pp. 833-842.

PLINT, A.G. and POLL, H.W. van de 1982. Post-depositional mud migration structures in the Tynemouth Creek Formation, Lower Pennsylvanian, southern New Brunswick (Abs). Maritime Sediments and Atlantic Geology, 18, p. 44.

POLL, H.W. van de. 1970. Stratigraphical and sedimentological aspects of Pennsylvanian strata in southern New Brunswick. Unpublished PhD. Thesis University of Wales, 140p. 
1972. Stratigraphic and economic geology of Carboniferous basins in the Maritime Provinces. Excursion Guidebook A60, XXIV International Geological Congress, Montreal. 96p.

POWELL, C.M. 1973. Clastic dikes in the Bull Formation of Cambrian age, taconic allochthen, Vermont. Bulletin of the Geological Society of America, 84, pp. 3045-3050.

POWERS, S. 1916. The Acadian Triassic. Journal of Geology, 24, pp. 1-26, 105122, 254-268.

RAY, P.K. 1976. Structure and sedimentological history of the overbank deposits of a Mississippi River point bar. Journal of Sedimentary Petrology, 46, pp. 788-801.

REEVES, C.C. 1970. Origin, classification and geologic history of caliche on the southern high plain, Texas and eastern New Mexico. Journal of Geology, 78, PP. 352-362.

RUITENBERG, A.A., GILES, P.S., VENUGOPAL, D.V., BUTTIMER, S.M., MCCUTCHEON, S.R. and CHANDRA, J. 1979, Geology and mineral deposits, Caledonia area. New Brunswick Department of Natural Resources, Mineral Resources Branch, Memoir No. 1, 213p.

RUST, B.R. 1972. Structure and process in a braided river. Sedimentology, 18, pp. 221-245.

SCHUMM, S.A. and LICHTY, R. W. 1963. Channel widening and flood-plain construction along the Cimarron River in S.W. Kansas. United States Geological Survey, Professional Paper, 352D, pp. 71-88.
STEEL, R.J. 1974. New Red Sandstone floodplain and piedmont sedimentation in the Hebridean Province. Journal of Sedimentary Petrology, 44, pp. 336357.

STEEL, R.J. and WILSON, A.C. 1975. Sedimentation and tectonism (?Permo-Triassic) on the margin of the North Minch Basin, Lewis. Journal of the Geological Society of London, 131, pp. 183-202.

TUNBRIDGE, I.P. 1981. Sandy, highenergy flood sedimentation - some criteria for recognition, with an example from the Devonian of S.W. England. Sedimentary Geology, 28, pp. 79-95.

WALKER, T.R. 1967. Formation of red beds in modern and ancient deserts. Bulletin of the Geological Society of America, 78, pp. 353-368.

WILLIAMS, G.E. 1966. Palaeogeography of the Torridonian Applecross Group. Nature, 209, pp. 1303-1306.

WILSON, A. C. 1980. The Devonian sedimentation and tectonism of a rapidiy subsiding, semi-arid fluvial basin in the Midland Valley of Scotland. Scottish Journal of Geology, 16, pp. 291-313.

WOODROW, R.L., FLETCHER, F.W. and AHRNSBRAK, W. F. 1973. Palaeogeography and palaeoclimate at the deposition sites of the Devonian Catskill and 01d Red facies. Bulletin of the Geological Society of America, 84, pp. 3051-3064.

WRAY, J. L. 1977. Calcareous Algae. Developments in palaeontology and Stratigraphy, 4. Elsevier, 185p. 